Iranian Journal of Breast Diseases. 2021;13(4):40-56.

Receive: $9 / 11 / 2020$

Accepted: 8/2/2021

*Corresponding Author:

drhajializadeh@gmail.com

Ethics Approval: IR.HUMS.REC.1398.328
Original Article

\section{An Investigation of the Effectiveness of Emotionally- Focused Couple's Group Therapy (EFCT) on Relational Aggression of Couples with Breast Cancer in Wives: A Semi-Experimental Study}

\author{
Hedayati $\mathbf{M}^{1}$, Hajializadeh $\mathrm{K}^{2 *}$, Hedayati $\mathbf{M}^{3}$, Fathi $\mathrm{E}^{4}$ \\ ${ }^{1}$ Department of Psychology, Kish International Branch, Islamic Azad University, Kish \\ Island, Iran \\ ${ }^{2}$ Department of Psychology, Faculty of Humanities, Bandar Abbas Branch, Islamic \\ Azad University, Bandar Abbas, Iran \\ ${ }^{3}$ Cellular and Molecular Endocrine Research Center, Research Institute for Endocrine \\ Sciences, Shahid Beheshti University of Medical Sciences, Tehran, Iran \\ ${ }^{4}$ Department of Counseling, Faculty of Humanities, Hazrat-e Masoumeh University, \\ Qom, Iran
}

\begin{abstract}
Introduction: Because of the nature of cancer and related hormonal changes, as well as the conditions resulting from stress tolerance, relational problems and aggression are major problems facing couples with breast cancer in wives. The aim of this study was to investigate the effect of emotionally focused couples therapy (EFCT) on relational aggression in couples with breast cancer in wives.
\end{abstract}

Methods: This study was conducted with a pretest-posttest design and a control group. Twenty-two couples meeting the inclusion criteria were selected by convenience sampling from among people with breast cancer living in Tehran and randomly assigned to the experimental and control group. The experimental group received a 6 -session (120 minutes per session) intervention of an adapted version of emotionally focused group therapy for couples (HMT). This intervention was meant to improve the psychological and relational indicators related to the quality of life of couples where the female partner was diagnosed with, or had a recurrence of, breast cancer and was in active treatment process or had gone through the treatments. The control group did not receive any intervention. Both groups answered the Buss-Perry Aggression Questionnaire (29-item instrument to measure physical aggression, verbal aggression, anger, and hostility) before and after the intervention. Analysis of covariance was used to evaluate the effect of treatment.

Results: The experimental group demonstrated a decline in the mean of all factors after receiving the training program, as compared to the control group. The decrease was 11.01 points for physical aggression, 5.78 for verbal aggression, 8.37 for anger, and 10.95 for hostility. In contrast, the control group had a decrease of 0.41 points in anger and 0.17 points in hostility factors. The control group also displayed an increase of 0.06 points in the mean scores on both physical and verbal aggression components. Analysis of covariance revealed that EFCT had a significant decreasing effect on all the components of aggression in the experimental group as compared to the control group $(\mathrm{P}<0.01)$.

Conclusion: Through the education of correct mutual emotional understanding for couples and creating an atmosphere of trust and communication between them, EFCT intervention provides a ground for increasing marital satisfaction and reducing aggression in couples coping with breast cancer in wives. Accordingly, the intervention can be used to improve the quality of marital relations.

Keywords: Emotionally Focused Couples Therapy, Relational Aggression, Couples, Breast Cancer 


\section{بررسى اثربخشى زوجدرمانى هيجانمدار به شيوه تروهى بر بران

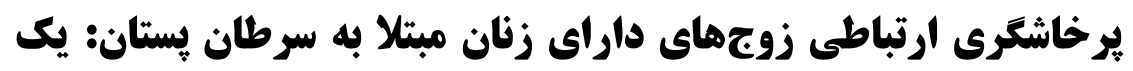

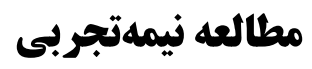

معصومه هدايتى'، كبرى حاجى عليزاده ז"، مهدى هدايتى "، الهام فتحى" ' كروه روانشناسى، واحد بينالملل كيش، دانشخاه آزاد اسلامى، جزيره كيش، ايران

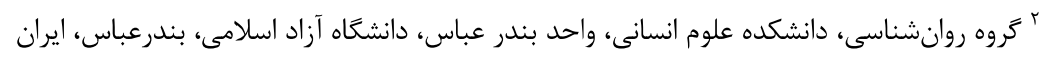

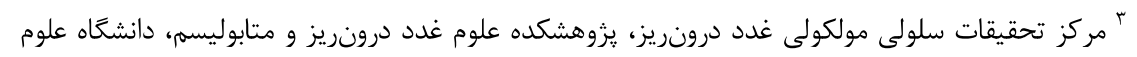
يزشكى شهيد بهشتى، تهران، ايران

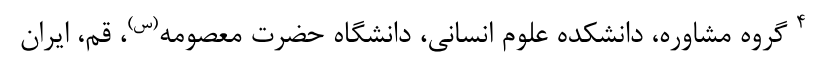

ous? مقدمه: مشكلات ارتباطى و يرخاشكرى در زوجهاى داراى زنان مبتلا به سرطان بهسبب ماهيت بيمارى و

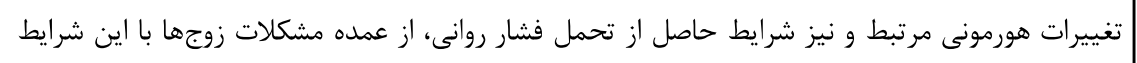

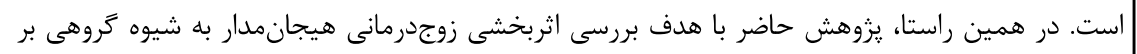

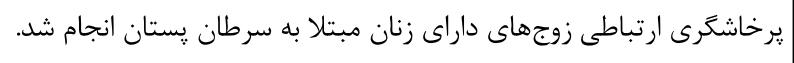

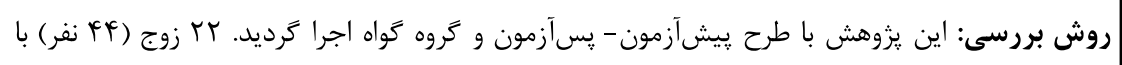

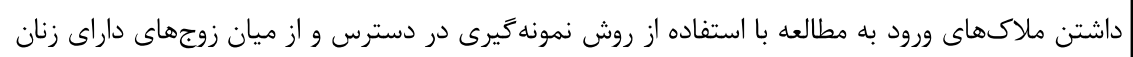

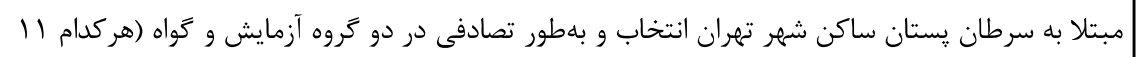

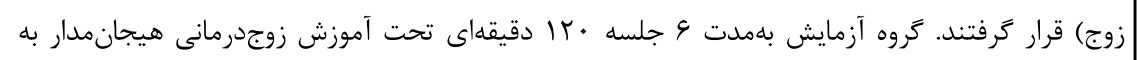

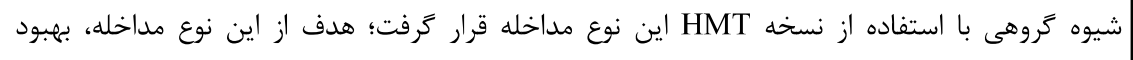

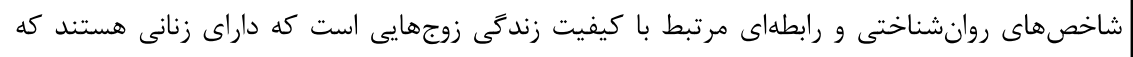

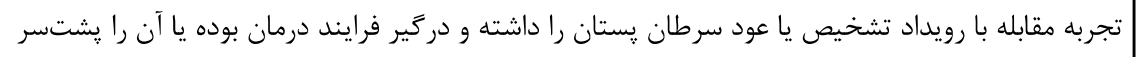

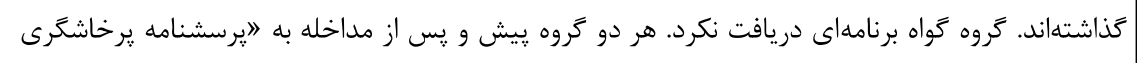

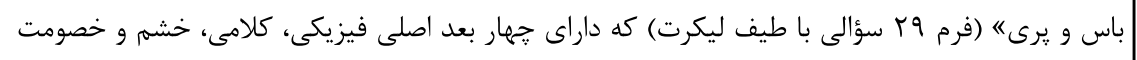

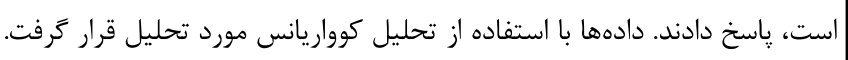

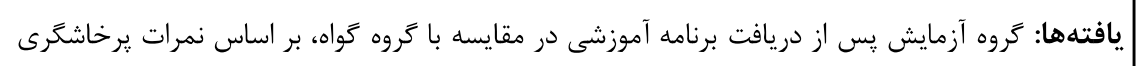

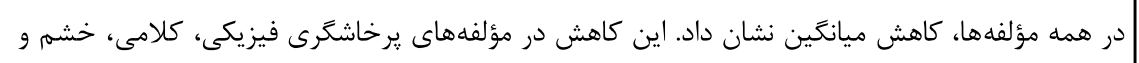

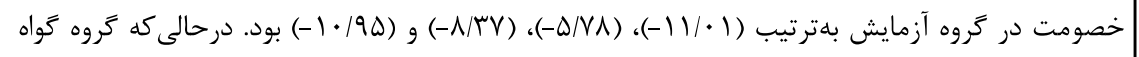

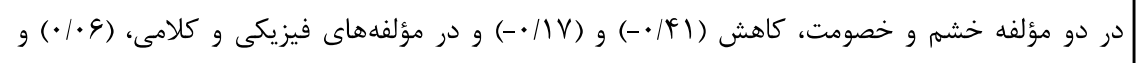

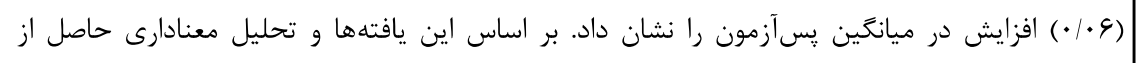

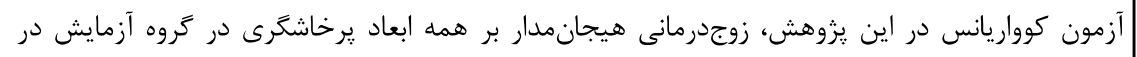

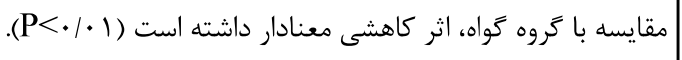
نتيجهَيرى: بر اساس يافتههاى بهدست آمده، برنامه مداخله زوجدرمانى هيجانمدار با آموزش درى

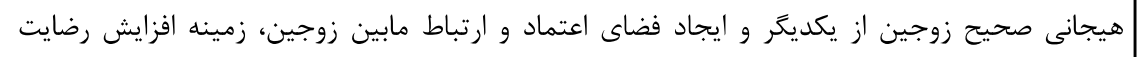

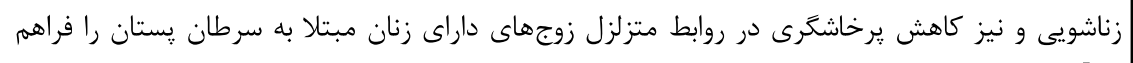

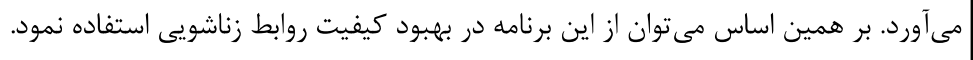

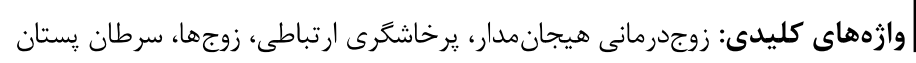

فصلنامه بيمارى هاى يستان ايران

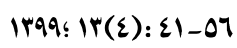

تاريخ ارسال: 99/N/19

تاريخ بذيرش: · ت

": نويسنده مسئول: drhajializadeh@gmail.com 
از سرطان را در سال 1 \·r به خود اختصاص داده و

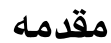
براساس جديدترين كزارش جهانى إيدميولوزيك سرطان، موسوم به GLOBOCAN انتظار مىرود كه موارد

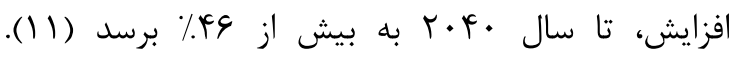

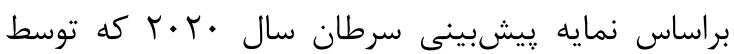

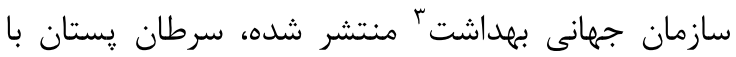

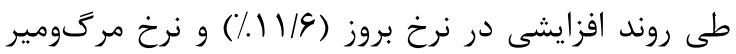

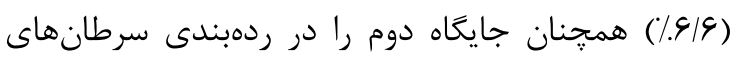
شايع و كشنده در جهان حفظ كرده است. اين روند، بهويزه در كشورهاى در حال توسعه و منطقه خاورميانه

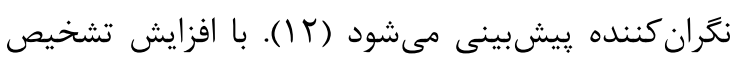
بهموقع و درمان مؤثرتر سرطان، ميزان بقاى بيماران

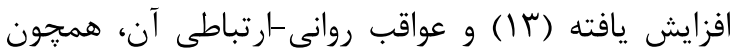

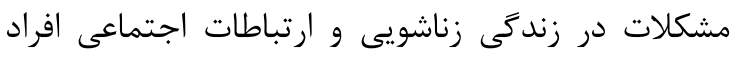

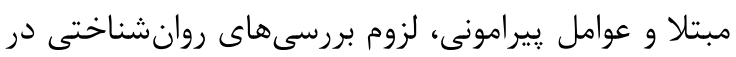

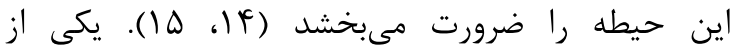



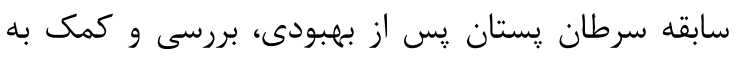

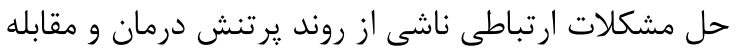

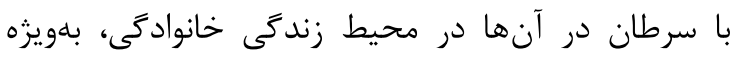

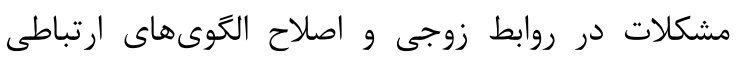

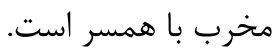
بررسىها كوياى اين مسئله است كه زنان داراى سرطان

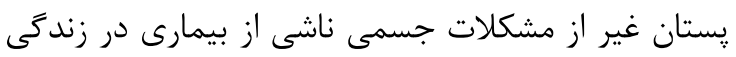

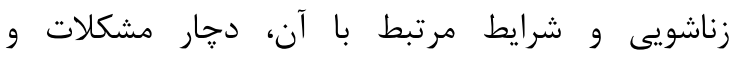

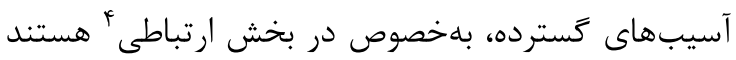

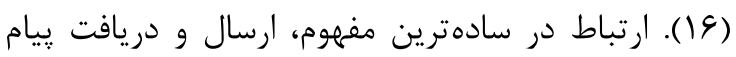

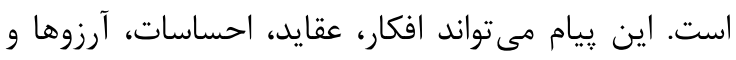
نيازهاى طرفين ارتباط باشد. ارتباط مؤثر همسران،

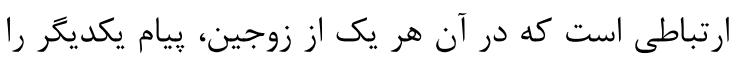

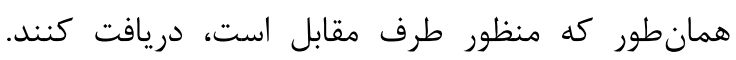
بهعبارت مشخصتر، اولين زمينه يِيوند زوجين، داشتن مان روابط و اولين مهارت لازم براى حفظ رابطه، داشتن زئن

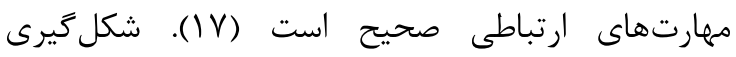
رفتارهاى دوسو

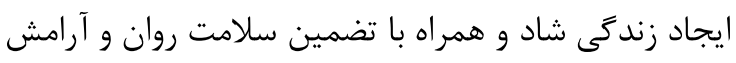

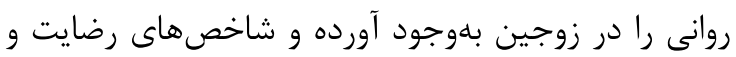

\footnotetext{
${ }^{3} \mathrm{WHO}$

${ }^{4}$ Relational
}

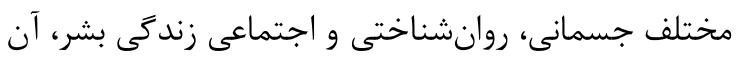
را به يكى از معضلهاى بزرى قرن تبديل كرده است (1).

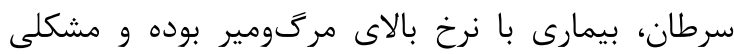
است كه اثرات زيادى بر ابعاد مختلف زندگى بـى افراد بهجا

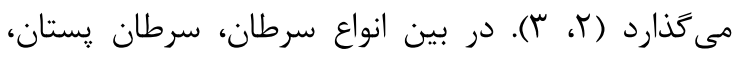

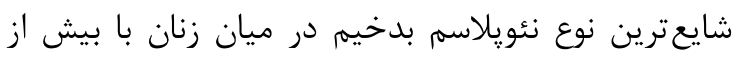

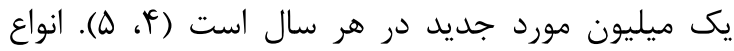
سرطان در ايران، بهعنوان كشورى در حال توسعه كه با هورد ديا دوران كذار جمعيتى روبهرو است، از جمله برانه مهرمترين اختلالات غيرواتير محسوب مىشوند كه بار مالى و انسانى قابلتوجهى را به نظام مراقبتهاى بهداشتى كشور تحميل

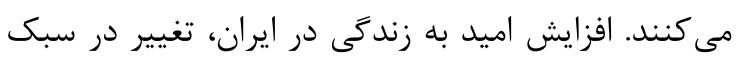
زندگى و همجنين توسعه روشهاى تشخيصى و درمانى، منجر به ظهور و تشخيص بدخيمى هاى قابلتوجهى شده

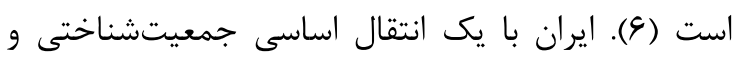

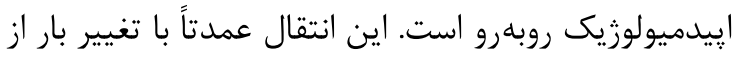
اتيولوزى واكيردارها' بهسمت بيمارىهاى غيرواگير ' همراه بوده كه در اين ميان سرطان بهعنوان سومين علت مرك

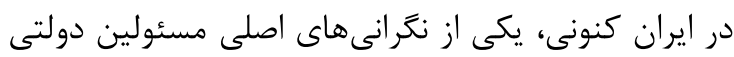

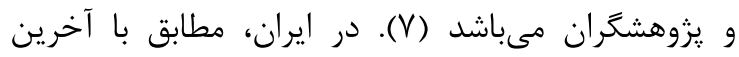

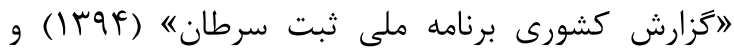

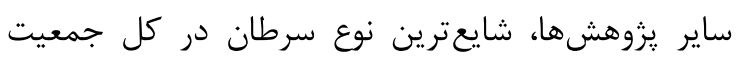
كشور و همجنين در جمعيت زنان، سرطان يستان اعلام

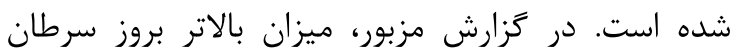
يستان در زنان ايرانى نسبت به ساير سرطان هاى شايع در

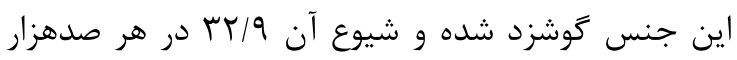

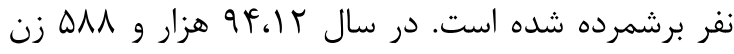

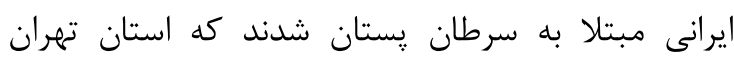

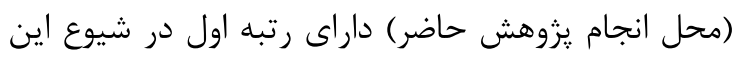

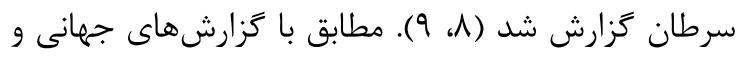
داخلى، نرخ بروز استانداردشده سنى سرطان يستان در ايران بالاتر از متوسط جهانى بوده (

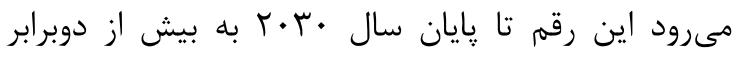

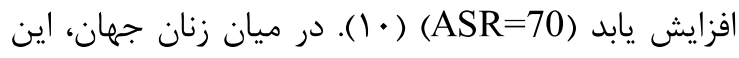

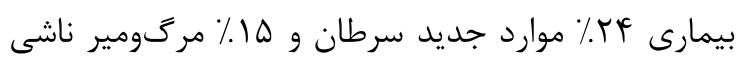

\footnotetext{
${ }^{1}$ Communicable Etiologies

${ }^{2}$ Non-communicable Diseases (NCDs)
} 
آموزش تخليه و بيان آن، زمينه آكاهىيابى از هيجانات

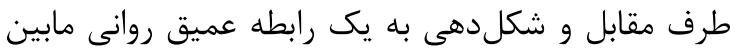
زوجين را فراهم مى آورد (Tه). بر اين اساس، كارسازى

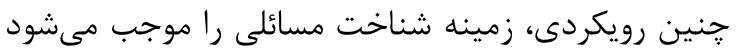
كه در شكل كيرى و ايجاد يرخاشكرى و كنترل آن در يكى

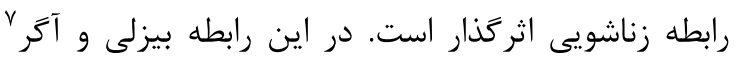

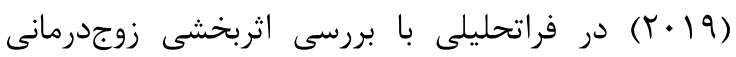

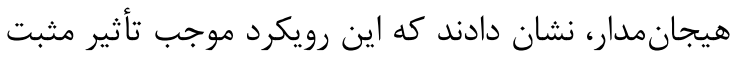
بر هيجانات، اصلاح الكوهاى غلط ارتباطى زوجها، افزايش

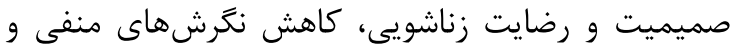

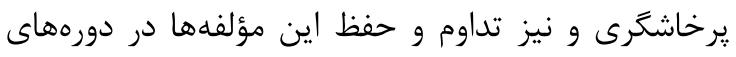

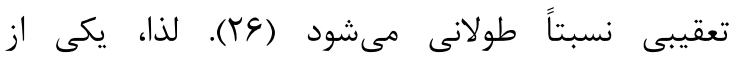
رويكردهاى رواندرمانى متعددى كه مىتواند در زمينه

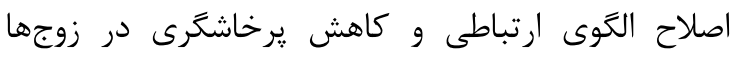
راهَّشا باشد، رويكرد زوجدرمانى هيجانمدار است كه كه بلويزه در سال هاى اخير مورد اقبال بوده است.

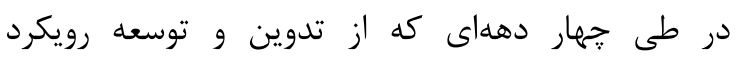

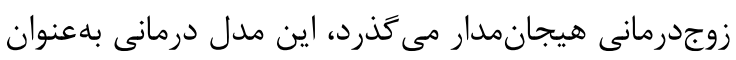
يكى از الكوهاى زوجدرمانى كه متكى به به بيشترين حمايتهاى يزوهشى از منظر تجربى است، معرفى شده

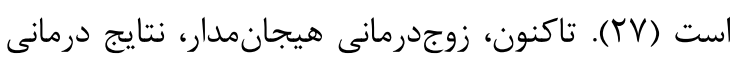

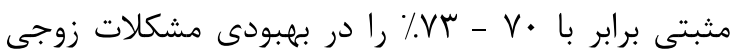

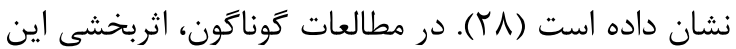

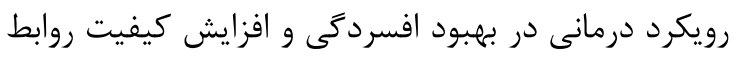

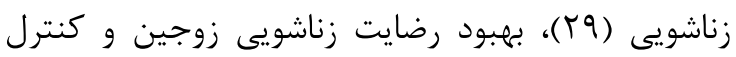
رفتار خانواده و همجنين كاهش تعارضات زوجها (•r)، افزايش رضايتمندى جنسى زوجين (آب)، بهبود الكَوهاى

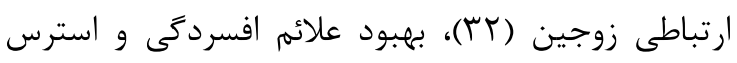

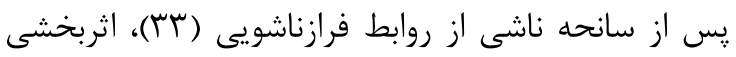

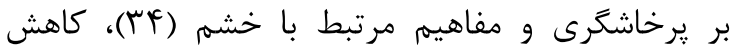

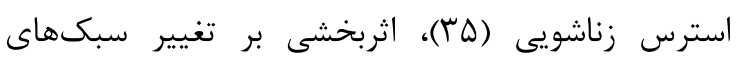

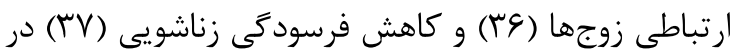
جمعيتهاى فاقد بيمارى زئشكى بررسى و تاييد شده

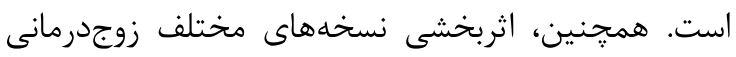

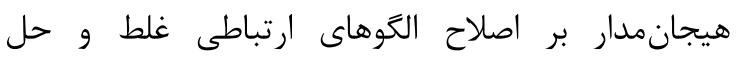
مشكلات زناشويى در زوجهاى دركير مقابله با آثار

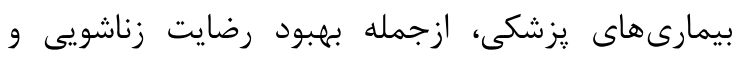

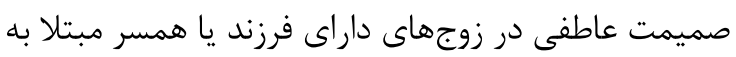

${ }^{7}$ Beasley \& Ager
كيفيت زندكى زناشويى را افزايش مىدهد (1)، 9 (1). اما

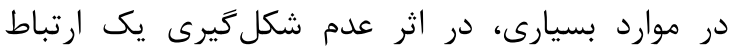

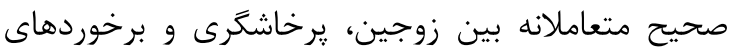
منفى ايجاد مىشوند، كه اين مقوله در خانوادههايى كه يكى از زوجين از مشكل جسمى حاد رنج مئبرد إدى مسئلهاى

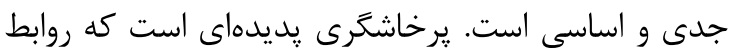

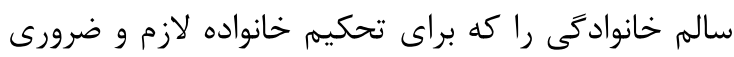
است، متزلزل ساخته و زمينه دورى و و فاصله كرفتن زوجين از يكديكر را موجب مى كردد (·r). يرخاشكرى در

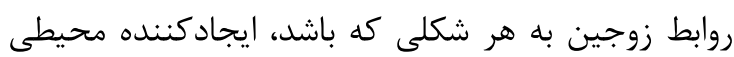

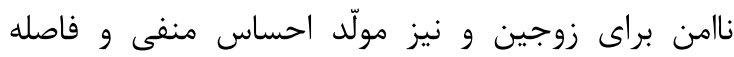

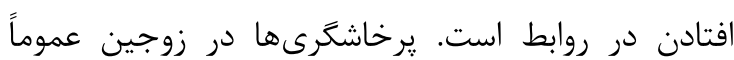
بهصورت كلامى و رفتارى ظاهر شده و زمينهساز ايجاد

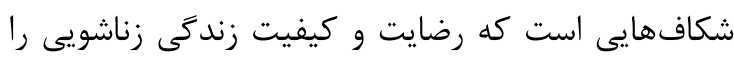
دجار آسيب كرده و عواقب منفى بسيارى در سازكارى

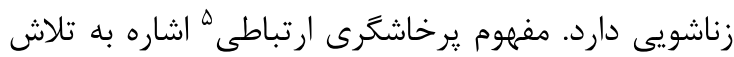

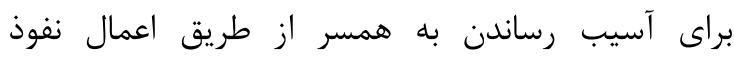

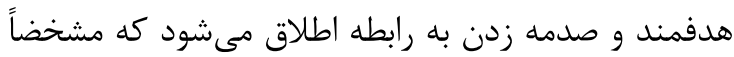

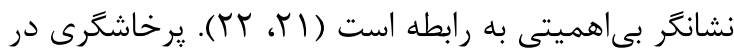
زوجهاى داراى زنان مبتلا به سرطان غالن رالباً نتيجه ماهيت

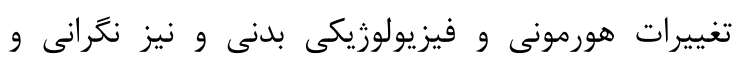
اضطراب فراگير ييرامون فرد مىباشد كه توجه به خويشتن

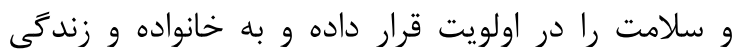

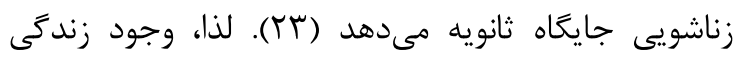

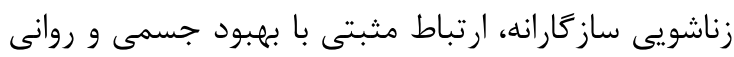

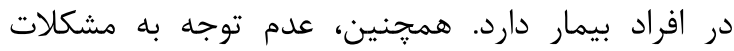

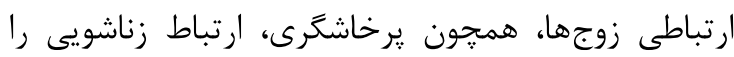
رفتهرفته بهسمت سردى و فاصله كرفتن مى كشاند (TF). (TF).

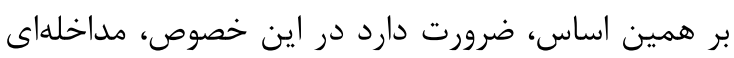
صورت يذيرد تا آسيبهاى موجود در داين اين حيطه به حداقل

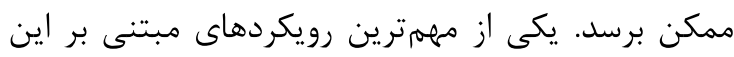

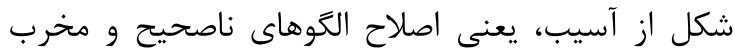

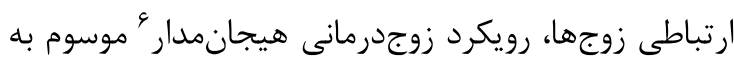

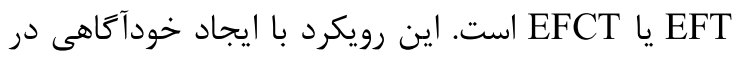

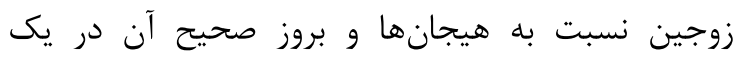
جارجوب خاص، از يكسو زمينه پالايش و ابراز آن در در

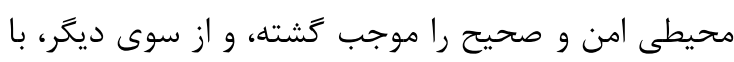

\footnotetext{
${ }^{5}$ Relational Aggression

${ }^{6}$ Emotionally Focused Couple Therapy (EFT/EFCT)
} 
يزشكى همجون سرطان، بهويزه در حوزه روابط عاشقانه

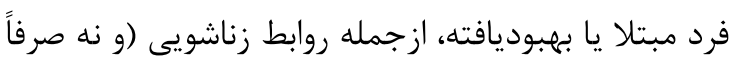
بعد فردى) است. در اين زمينه، روابط زناشويى در زوجهايى كه در حال مقابله با اثرات سوء سرطان هستند، هم بهعنوان عاملى تاثير كذار و هم تاثيريذير، در نظر كرفته

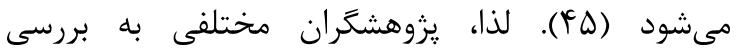
اثربخشى رويكرد زوجدرمانى هيجانمدار بر زوجهاى داراى بردي

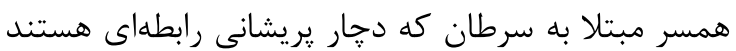

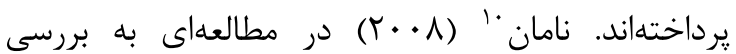
اثربخشى زوجدرمانى هيجانمدار بر زنان مبتلا به سرطان

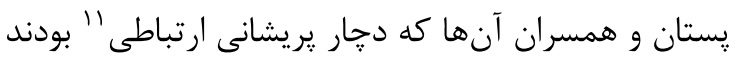

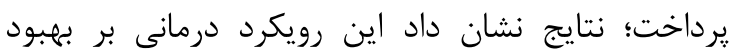
رضايت از رابطه و كيفيت زندگى زوجينى كه تحت درمان

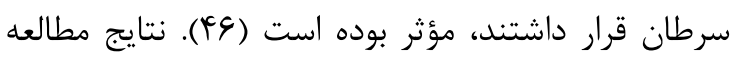

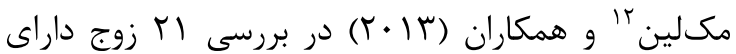
يريشانى ارتباطى كه يكى از زوجين مبتلا به سرطان

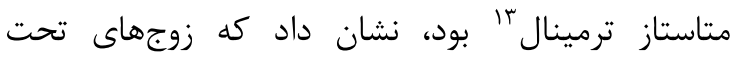

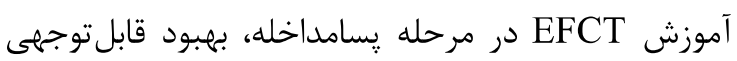
در شاخصهاى رضايت زناشويى و افرايش تجربه همدلى با همسر مراقب خود نسبت به زوجهايى كه فقط مراقبتهاي

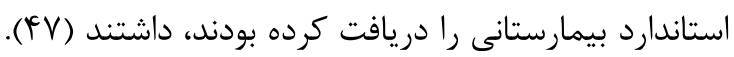

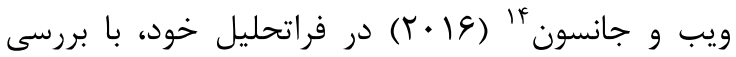
קند دهه مطالعات زوجدرمانى هيجانمدار، نشان دادند كه

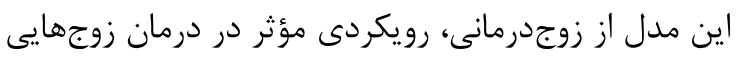

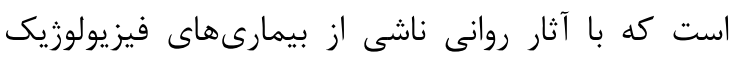

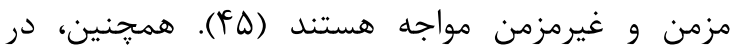

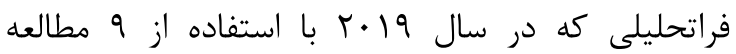

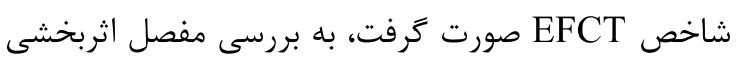
اين رويكرد درمانى در دو دهه كذشته يرداخته شد، كه

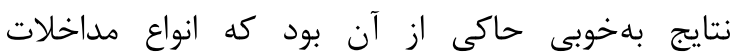

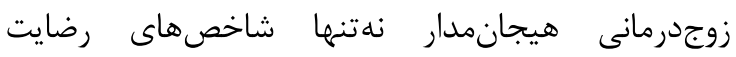
Hedge's g coefficient) زناشويى را بهبود مىبخشاني

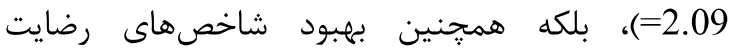

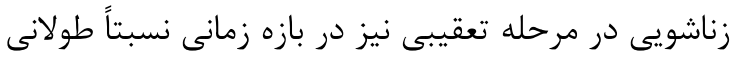

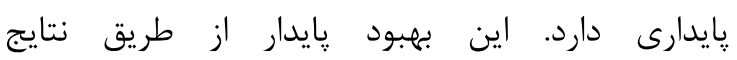

\footnotetext{
${ }^{10}$ Naaman

${ }^{11}$ Relational Distress

${ }^{12}$ McLean

${ }^{13}$ Terminal Metastatic Cancer

${ }^{14}$ Wiebe \& Johnson
}

بيمارى مزمن غيرسرطانى (همراه با ثبات اثربخشى با

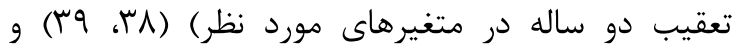
همجنين زوجهاى درگير مقابله با عواقب روانى و ارتباطى دوري ابتلاى يكى از زوجين به سرطان، ازجمله بهببود كاركرد

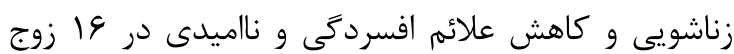

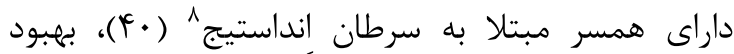
كاركرد ارتباط جنسى و عاطفى در زوجهايى كه زن ين يا مرد


مشكلات بينفردى در روابط عاشقانه در زوجهايى كه زوجه مبتلا به سرطان پستان بوده (T) (F) تاييد شده است.

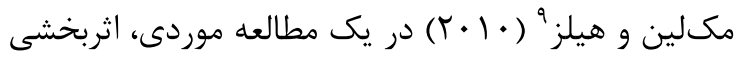
زوجدرمانى هيجانمدار را در يكى زن و مرد كه در آن آن آن زوجه مبتلا به سرطان بدخيم (سرطان تخمدان متاستاتيك) بود، مورد بررسى قرار دادند. نتايج نشان داد اد ادران

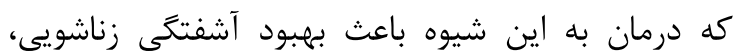
افزايش اميد به زندكى، كاهش دردهاى فيزيولوزيكى،

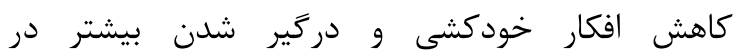

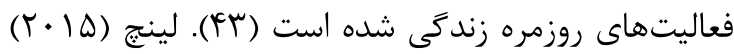

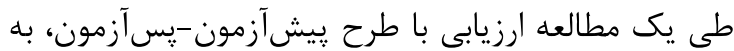

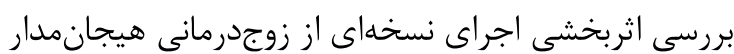

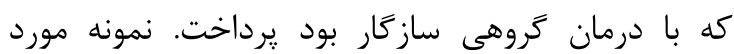

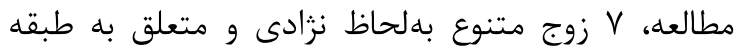
متوسط جامعه بودند كه با رويداد تشخيص و درمان

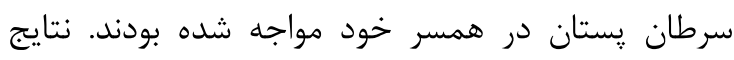
نشان داد كه زوجهاى تحت درمان گروهى يس إز دريان جلسات زوجدرمانى هيجانمدار، در شاخصهاى سلامت دان

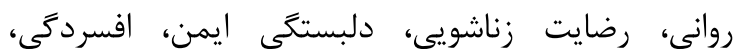
يرخاشكرى، و آسيبهاى تروماتيك ناشى از روند مقابله با نائ

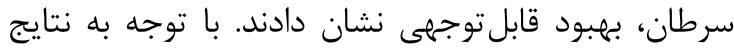
اندازهكيرى مكرر ANOVA، اندازه اثر قابل توجهى (از

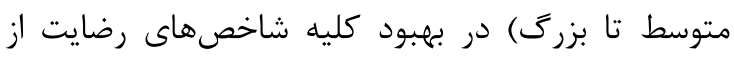
رابطه زناشويى و كاهش تأثير تروماى ناشى از تشخيص و

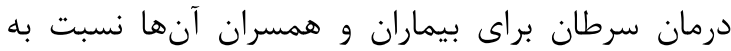
مرحله پِيش از مداخله تزارش شد. همجنين، تاثير مداخله

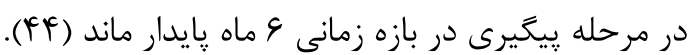

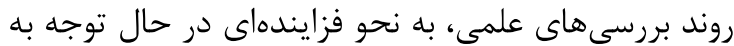

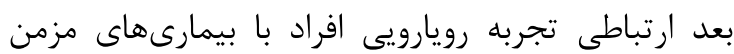

\footnotetext{
${ }^{8}$ End-stage Cancer

${ }^{9}$ McLean \& Hales
} 
بايسته است توجهى ويزه به آنها شود. با توجه به آنجه كفته شد، رويكرد زوجدرمانى هيجانمدار كه رويكرها

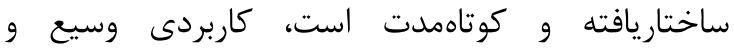
سهل النتيجه در حل مشكلات هيجانى و عاطفى زوجين دجار يريشانى ارتباطى دارد. در همين راستا، اين تحقيق ديق بهدنبال بررسى اثربخشى مداخله گروهى با استفاده از اين رويكرد بر كاهش يرخاشكرى ارتباطى در زوجهاى داراى

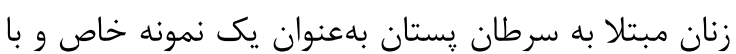
ملاحظات ويزه مىباشد.

\section{مواد و روشها}

يزوهش حاضر، يك كار آزمايى بالينى مراقبت حمايتى با

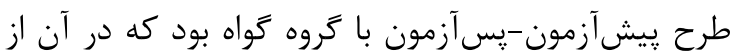

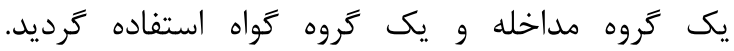

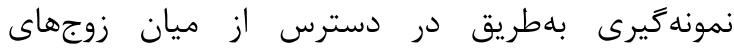
مراجعه كننده به مركز تحقيقات سرطان يستان شهر تهران

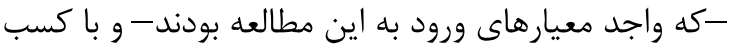

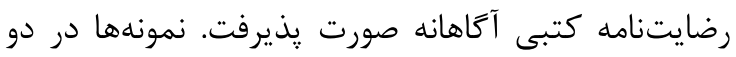

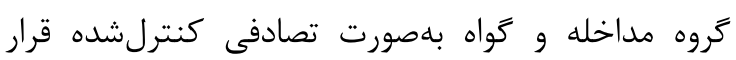
كرفتند. مطابق ورود، بيماران در جلسه اول به دو دراه

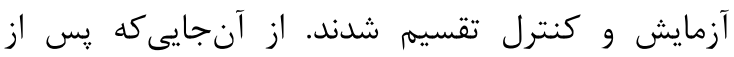

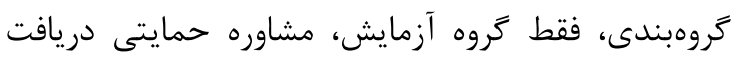

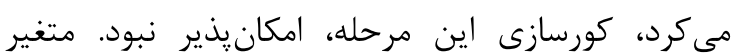
مستقل، آموزش زوجدرمانى هيجانمدار و متغير وابستهانها يرخاشكَى ارتباطى در زوجين بود. شركت كنندكان در دراني

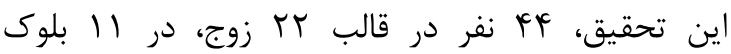
جهارتايى وارد مطالعه شدند. در داخل هر بلوك زوجين بهصورت تصادفى به يكى از كروه هاى مداخله و عدم

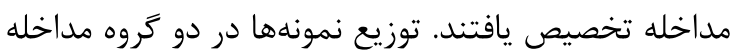

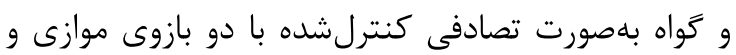
نسبت تخصيص 1:1 بود. جهت تعيين حجم نمونه، محاسبه حداقل حجم نمونه بر اساس جهار مؤلفه

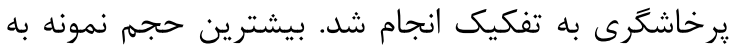

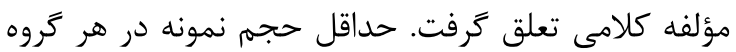

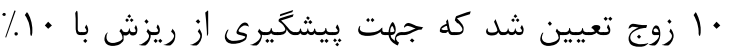

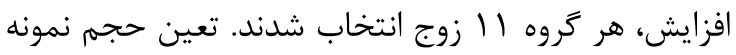

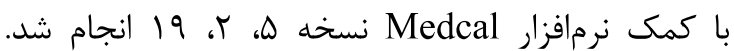

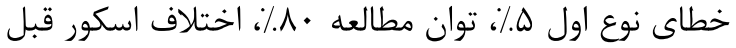

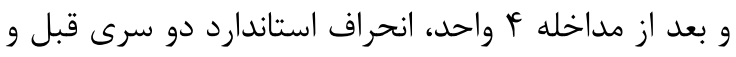

آزمون فريدمن و آزمون تعقيبى ويكاكس، مشهود بود (ن) $\left(\chi^{2}=6.500 ; p=0.039\right)$

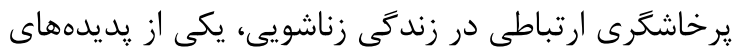

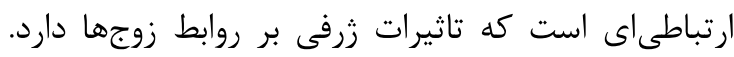

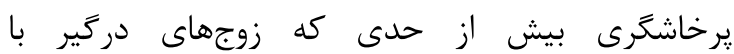
بيمارىهاى مزمن در روابط زناشويى خود تجربه مى كنند،

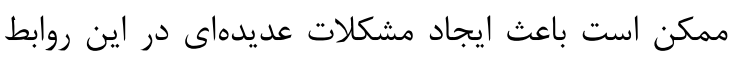

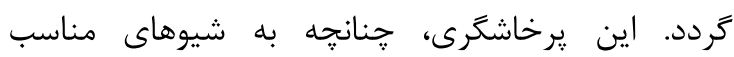
مديريت و درمان نكردد، آثار زيانبار خود را بردان برد رابطه

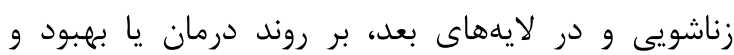

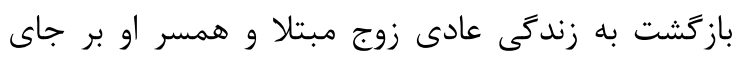

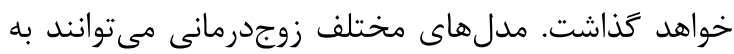

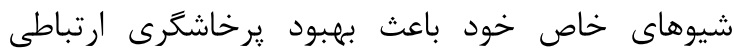

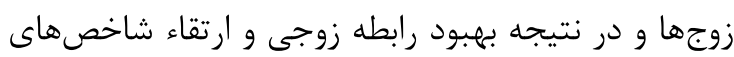
رضايت زناشويى و مشاركت بهتر زوج بيمار در روند درمان كردند. نتايج تحقيقات درخصوص اجراى رويكرد مداخلهاى ني

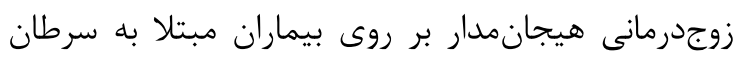
مى تواند در بيمارستانها، كلينيكها، مراكز درماني، دراني، مراكز

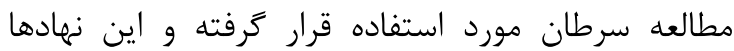
مىتوانند جهت ارتقا شاخصهاى سلامت روانى بيماران

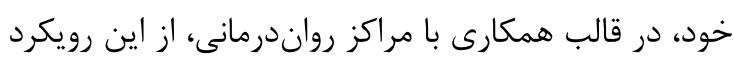

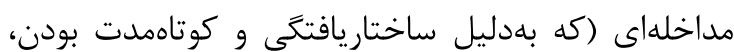
كاربردى وسيع و اجرايى فاقد دشوارى در حل مشكلات

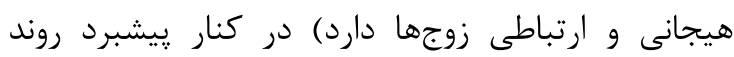
درمان استاندارد يزشكى، بهره بخيرند. با عنايت به مطالبى دئ دئي

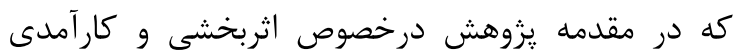
شيوه زوجدرمانى هيجانمدار در بهبود مسائل زوجى بيان

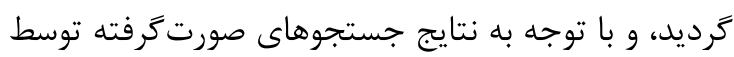
يزوهشكران كه حاكى از آن بود كه تاكنون تأثير رويكرد

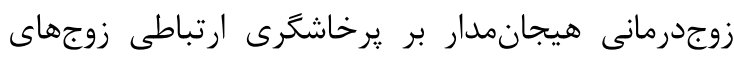

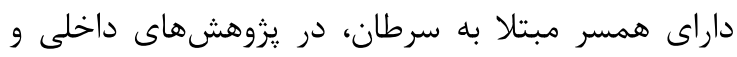

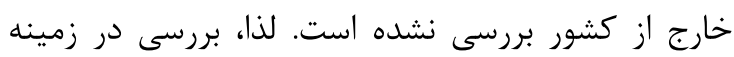

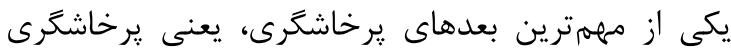

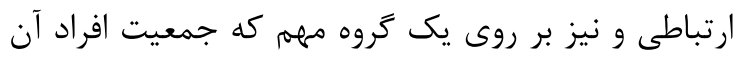

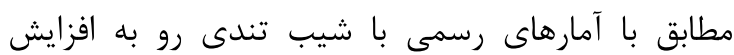
است، يعنى زوجهاى داراى زنان مبتلا به سرطان يستان، ازجمله كاستىهاى تحقيق در اين حيطه در ايران

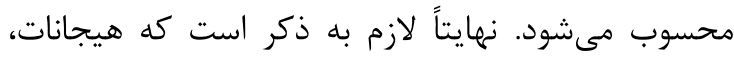

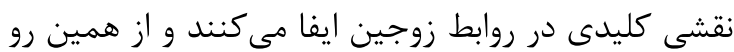


بطور تصادفى به دو گروه آزمايش (مداخله) و گَواه (عدم مداخله) قرار كرفتند. كروه آزمايش بلمدت ع ع جلسه (آنلاين با استفاده از

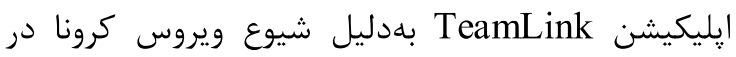
حين انجام تحقيق و بهجهت رعايت يروتكل هاى بهداشتى) بهصورت هفتكى و هر جلسه بلمدت • rا دقيقه (در دو

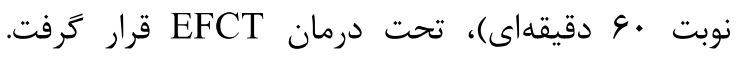

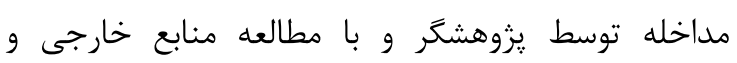
داخلى برنامه آموزشى موردنظر صورت كرفت. جهرت حصول اطمينان از همراهى مؤثر زوجها با جلسات آنلاين،

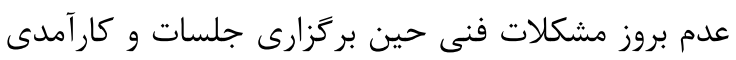

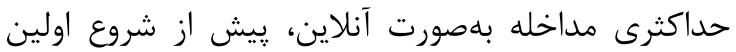
جلسه مداخله، براى هر زوج بهطور جداكانه نحوه نصب و

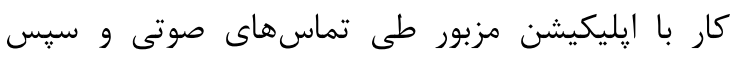

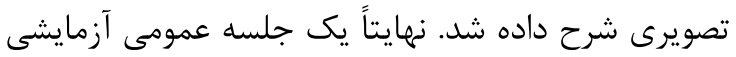
با شركت همه زوجهاى شركت كننده بركزار ترديد و نكات

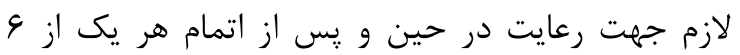

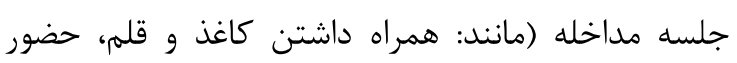
همزمان زوجين در كنار هم، آنلاين شدن در يك محيط هدأندا

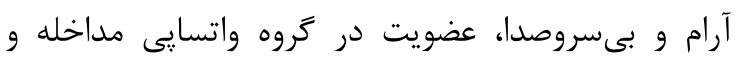
دسترسى به محتواى تصويرى و متنى مداخله (ازجمله

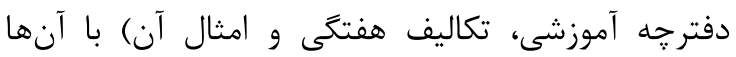
تمرين و كوشزد شد. كليه جلسات آنلاين مداخله،

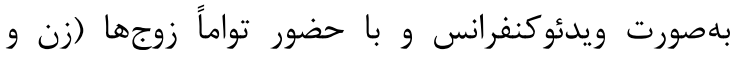

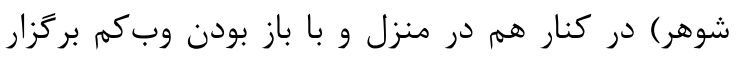

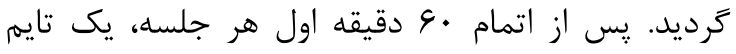
تنفس به زوجها داده مىشد. همجنين، در كليه جلسات يك نفر، بهعنوان دستيار مداخله كر حضور داشت.

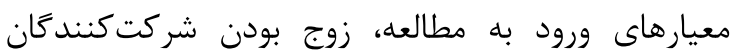

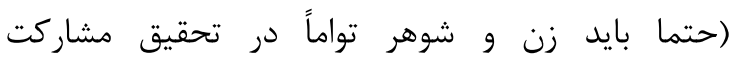

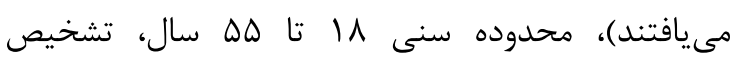

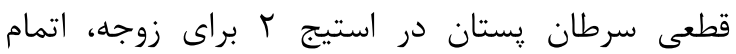
درمانهاى مرسوم (جراحى، شيمىدرمانى، راديوترايى و

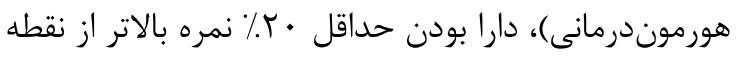

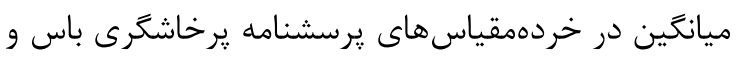
يرى (شايان ذكر است تدوينكران يرسشنامه موردنظر در بران

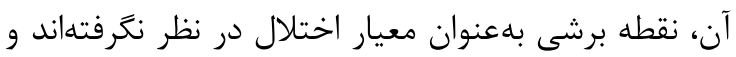

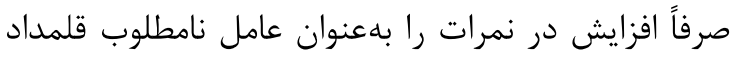

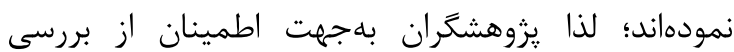

بعد ץ واحد و نسبت گروهها ا به ا در نظر گرفته شد. كفتنى است، صحت انتخاب حداقل حجم نمونه در رايان مطالعه با توجه به مشاهده اختلاف \& واحدى و انحراف

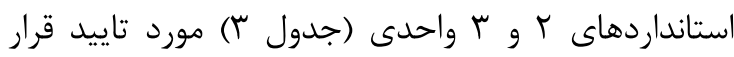
كرفت. برنامه آموزشى زوجدرمانى هيجانمدار در تابستان

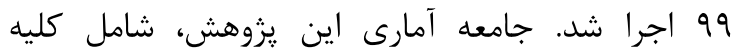

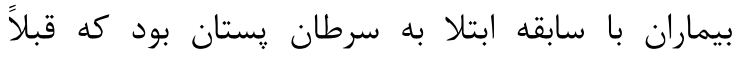

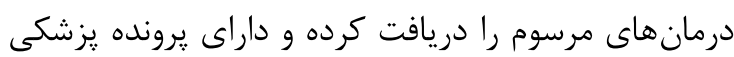
در مركز تحقيقات سرطان يستان شهر تهران بودند و وردان

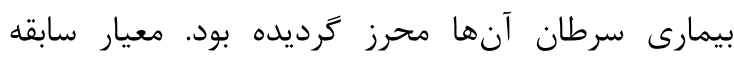

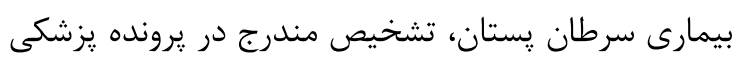

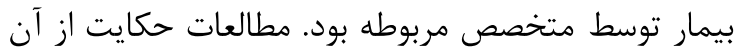
دارد كه اكثريت مبتلايان به سرطان پستان، در مرحله

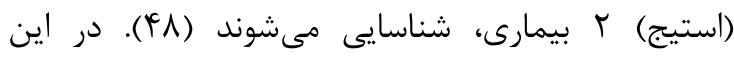

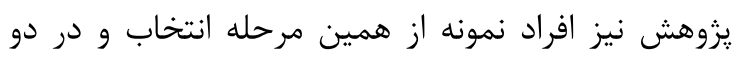

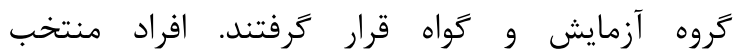
شركت كننده همكى درمانهاى اصلى و درمان هانى كمكى

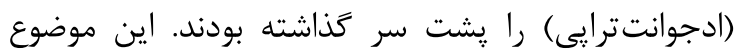
بهعنوان شرط ورود به مطالعه در نظر كرفته شد. اقدام به

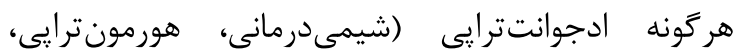
راديوترايى) سبب خروج از مطالعه مىشد. خوشبختانه

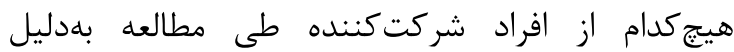
ادجوانت ترايى نياز به خروج ييدا نكردند.

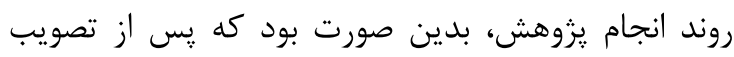

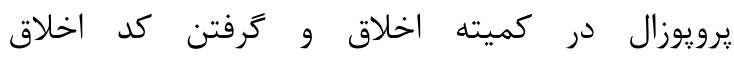
(IR.HUMS.REC.1398.328) با ارائه معرفىنامه، از از ميان زوجهايى كه در مركز تحقيقات سرطان يستان شهر

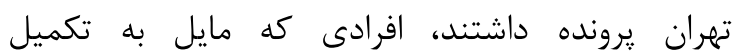

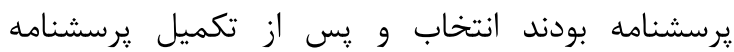

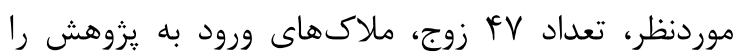

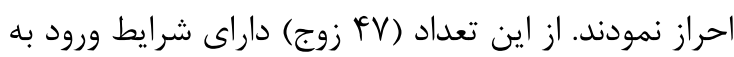

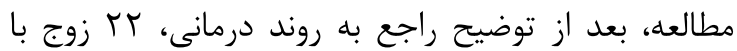

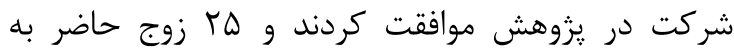

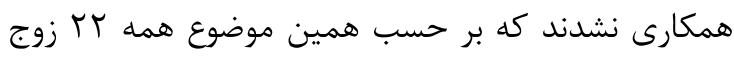

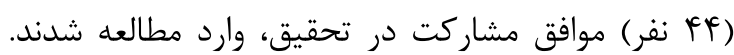
اين تعداد زوج، بر اساس محاسبه حداقل حجم نمونه،

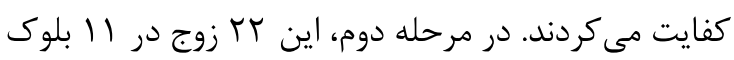
جهارتايى وارد مطالعه شدند و در داخل هر بلوكى زورجين دردين 


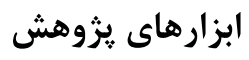

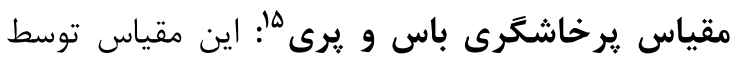
باس و يرى بهمنظور سنجش جهار جنبه يا مؤلفه از ياز

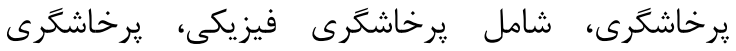

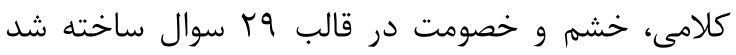

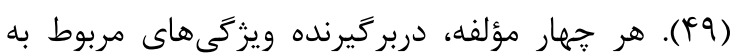
يرخاشكرى هستند كه مشتمل بر ابعاد فيزيكى (9 سوال: اشاره به آسيب رساندن جسمى)، كلامى (له سوال: اشاره

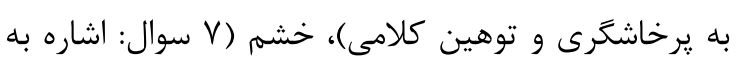
بر افروختگى و عصبانيت مداوم) و خصومت (^ سوال:

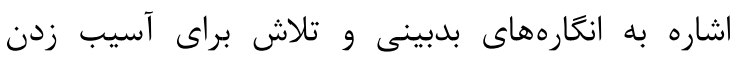

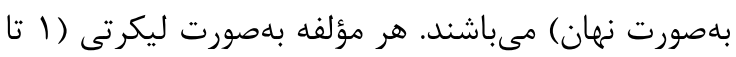

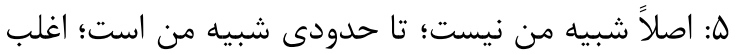

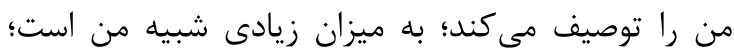

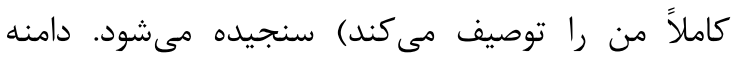

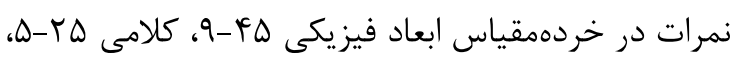

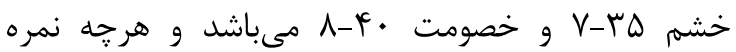

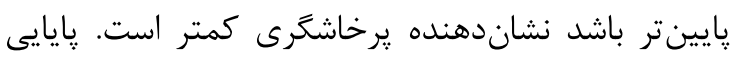

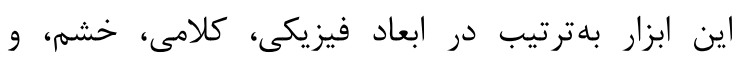

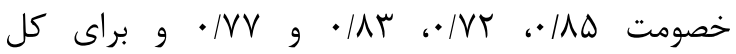

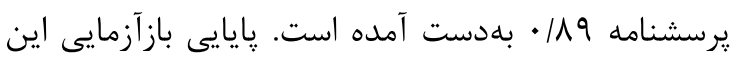

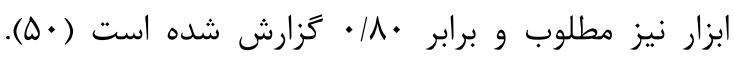

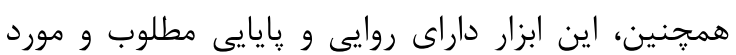

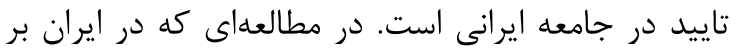

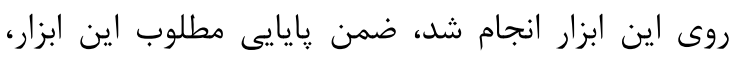

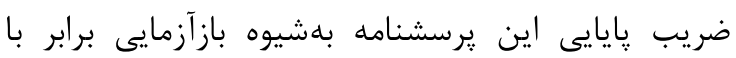

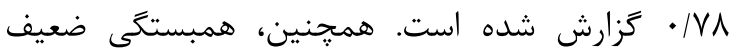

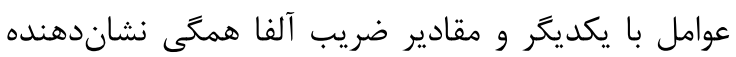

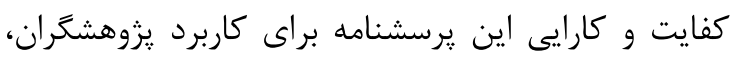

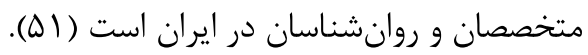

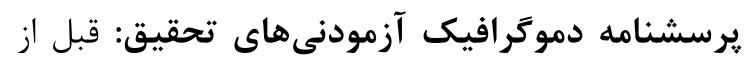
اجراى مقياس يرخاشكرى باس و يرى، اطلاعات اوليه

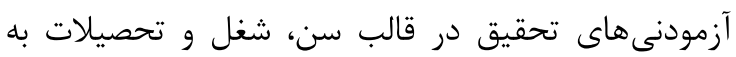
تفكيك جنسيت از آزمودنى ها اخذ ترديد.

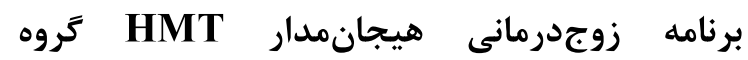
دريافتكننده زوجدرمانى هيجانمدار: در اين كروهان

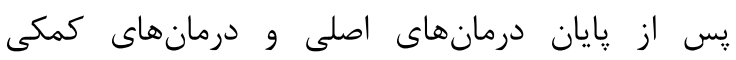

اثربخشى و جلوكيرى از بروز خطاهاى استنباطى در نتايج

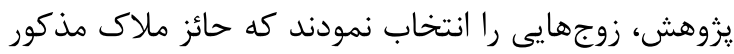
باشند)، تسلط به زبان فارسى، سواد خواندن و نوشتن،

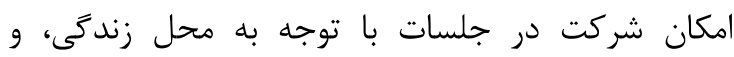

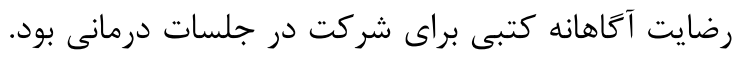

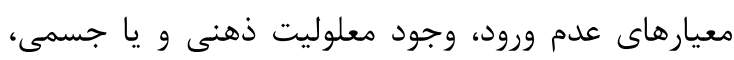

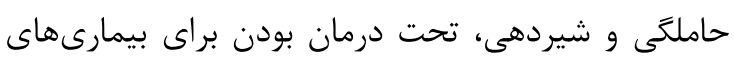

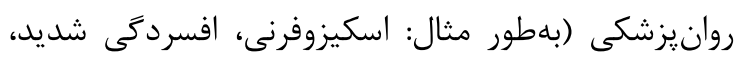

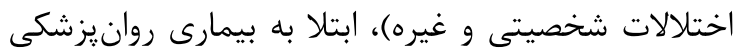

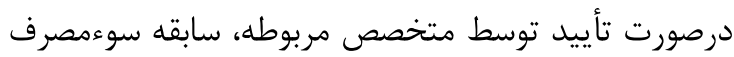

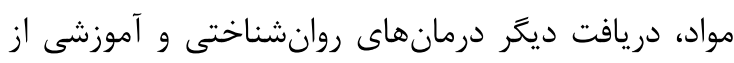
زمان تشخيص بيمارى بود. لازم به ذكر است هر بيمار هر دران

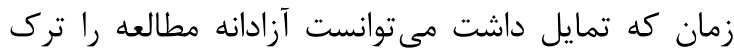

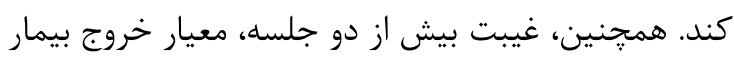

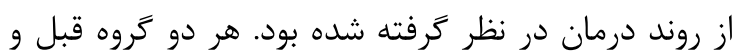

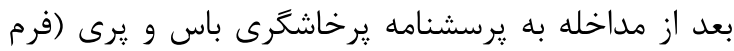

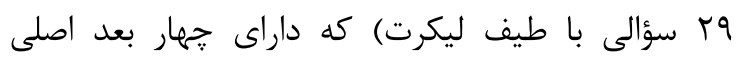

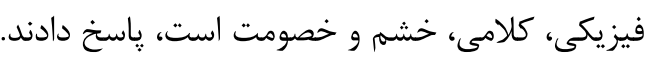

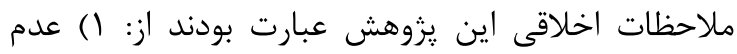

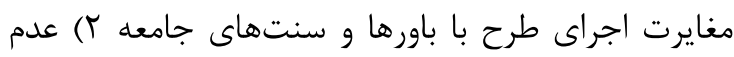

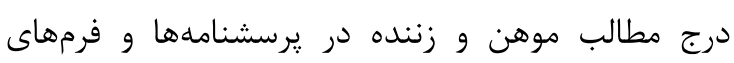

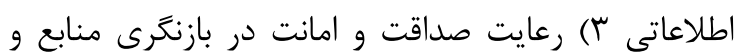

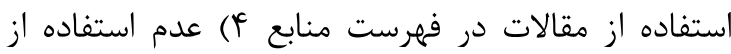

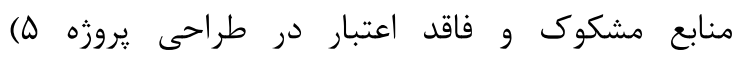
به كاركيرى مناسبترين روش تحقيق و جديدترين تكنيك برك 9) عدم بهره

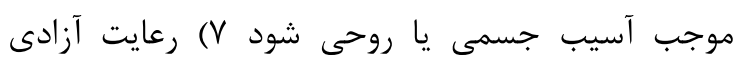

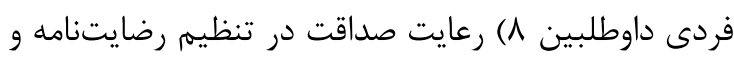
كسب امضاى داوطلبين 9) درج يذيرش مسئوليت جبران

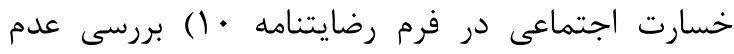

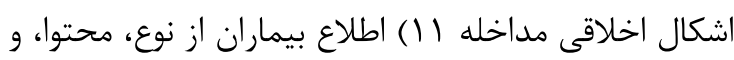
هدف مداخله Y I) جبران خسارات سهوى وارده به افراد

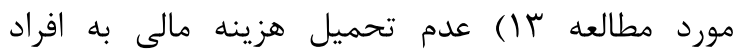

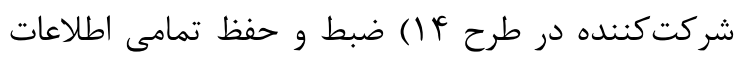
شخصى مربوط به افراد شركت كننده در طرح ها لا ) تفسير نتايج مطالعه براى شركت كنندكان درصورت تمايل و و (1) راهنمايى شركت كننده درصورت مشاهده هركونه اختلال روانى.

${ }^{15}$ Buss-Perry Aggression Questionnaire (BPAQ) 
راه كارهاى حل مسئله مرتبط با آن، آموزش و تمرين داده

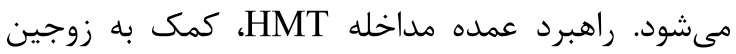
براى توسعه مهارتهاى ابراز هيجانى بيشتر و به اشتراك

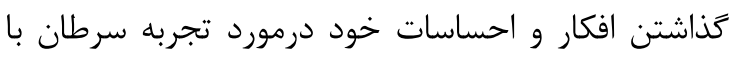
همسر است. در واقع، هدف كلى، تسهيل حمايت عاطفى و و اجتماعى همسران از يكديخر است. خلاصه جلسات مداخله به شرح مندرج در (جدول () مى اشبد:

جدول ا: برنامه زوجدرمانى هيجانمدار HMT

\begin{tabular}{|c|c|}
\hline 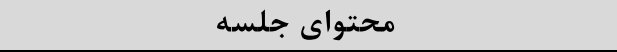 & 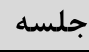 \\
\hline ايجاد رابطه درمانى و بازشناسى كفتو كوهاى مخرب & 1 \\
\hline يافتن نقاط جريحهدارشده در زوجين & r \\
\hline رويارويى با لحظات بحرانى: آغاز هذيرش و مسئوليتيذيرى & $r$ \\
\hline بخشش رنجشها و اعتماد دوباره & r \\
\hline بيوند مجدد از طريق رابطه جنسى و نزديكى جسمى & $\Delta$ \\
\hline جحَّونَّى مراقبت از خود و رابطه زناشويى خود & 9 \\
\hline
\end{tabular}

بهمنظور آناليز دادهها، آمار توصيفى و تحليلى بهكار كرفته شد. براى توصيف تغييرات در متغير وابسته، با توجه به

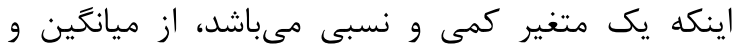

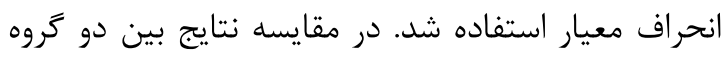

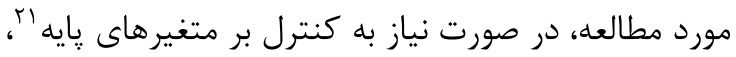
برحسب نوع متغير، از مدلهاى تركيبى تحليل ركرسيون و سيس تحليل واريانس با كنترل متغير تصادفى كمكى يا ندان هميراش (كوواريت) كه همان تحليل كوواريانس (مانكووا)

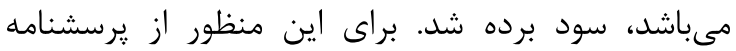

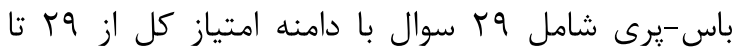

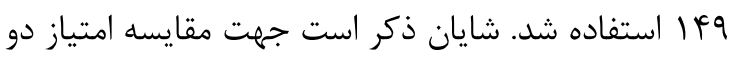
كروه مداخله و غيرمداخله، از جمع امتياز يرسشنامه استها مربوط به هر زوج بهره كرفته شد. استفاده از تحليل

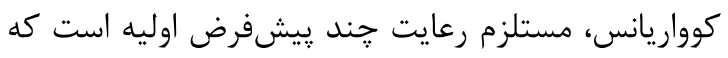
درصورت رعايت آنها، مىتوان از اين آزمون استفاده كرد.

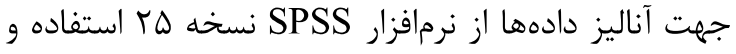

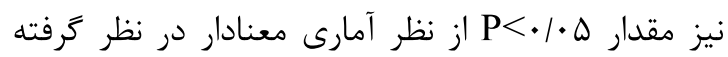

درخصوص تعديل متغيرهاى مخدوش يرخاشكرى بعد از مداخله، جهت كنترل متغيرهاى

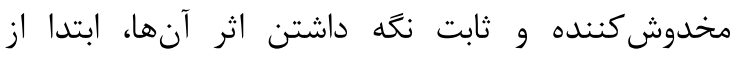

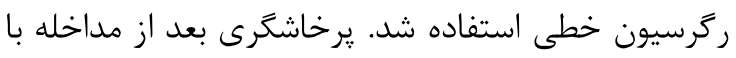

${ }^{21}$ Baseline
(ادجوانت ترايى) در زنان مبتلا به سرطان يستان، به مدت 4 جلسه و به صورت زوجى صورت يذيرفت. در اين يزوهش، نسخهاى از برنامه زوجدرمانى هيجانمدار به شيوه

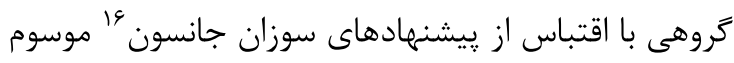

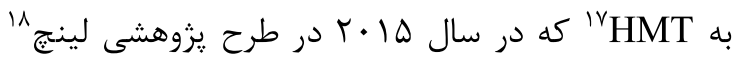
جهت مداخله در زوجهاى داراى زنان مبتلا به سرطان

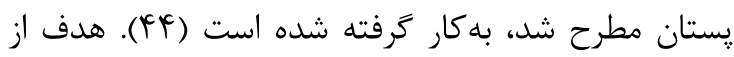

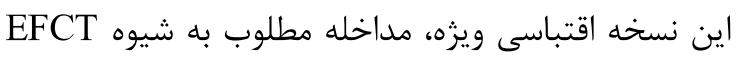
جهت بهبود شاخصهاى روانشناختى و رابطهاى مرتبط با كيفيت زندكى زوجهايى است كه داراى زنانى هستند كه

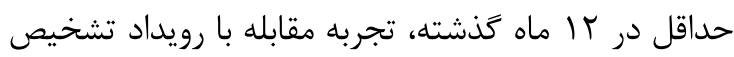

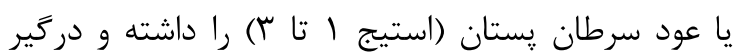
فرايند درمان بوده يا آن را يشتسر كذاشتهاند. نسخه

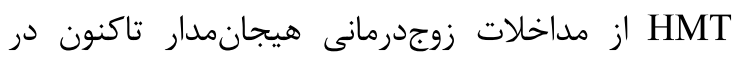

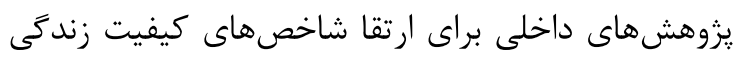
زناشويى در زوجهاى دركير مقابله با سرطان، به كار كرفته

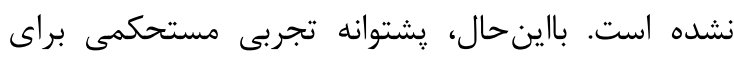

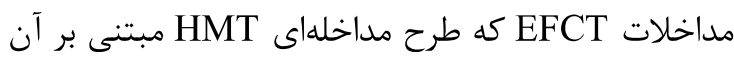
است، وجود دارد. روش HMT اولين بار توسط ديوى و و

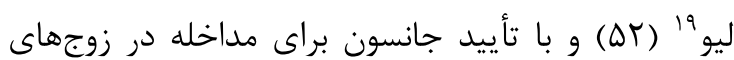

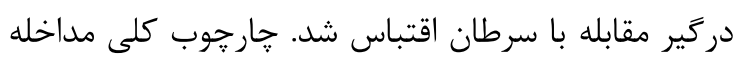

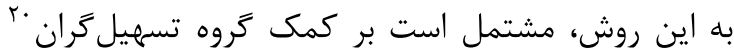

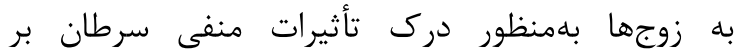

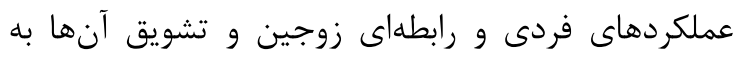
بيان تجربيات، هيجانات و انتظارات خود. در اين مدابن وداخله،

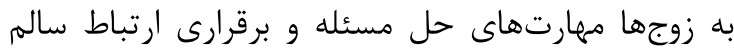

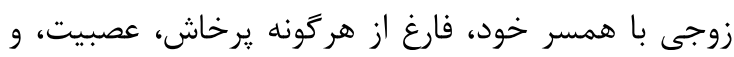
فرسايش آموخته مىشود تا در برخورد و مقابله با رويداد سرطان، به موضعى منطقى برسند. جلسات مداخله

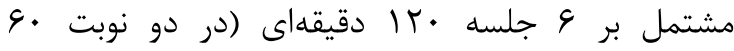
دقيقهاى) است كه در طول جلسات، همواره دو تسهيل حضور دارند تا شركت كنندًان، مشاركت كامل و فعال خود را حفظ كنند. در هر يك از جلسات، يكى از از كفتتوهاى مخرب زناشويى و شيوههاى ناصحيح برقرارى

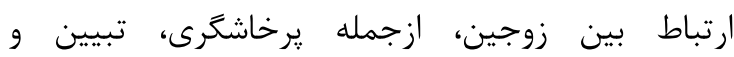

\footnotetext{
${ }^{16}$ Suzan Johnson

${ }^{17}$ Hold Me Tight (HMT)

${ }^{18}$ Lynch

${ }^{19}$ Davey \&Liu

${ }^{20}$ Facilitators
} 
نمرات يرخاشكرى ارتباطى بعد از مداخله نسبت به قبل از

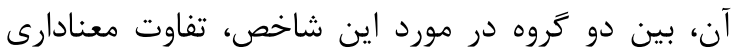

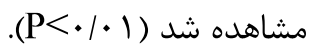

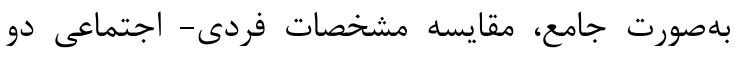

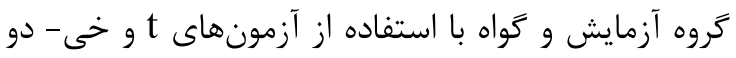
انجام شد و نتايج حاكى از عدم تفاوت معنادار بين آنها

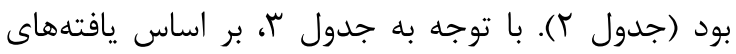

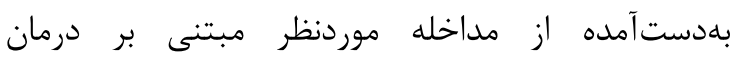

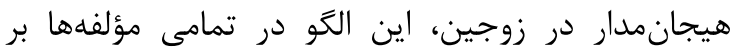

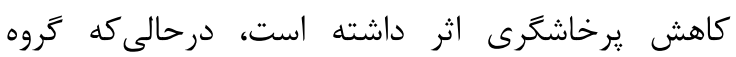



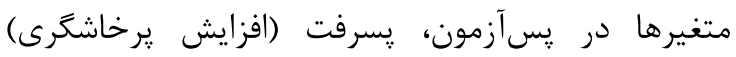

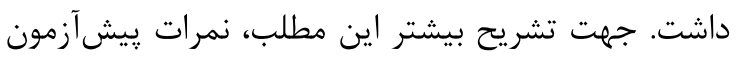

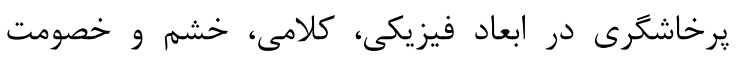
بهترتيب (T)

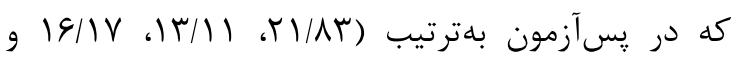

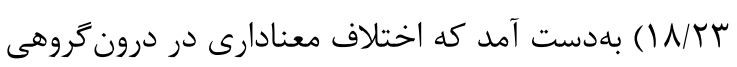

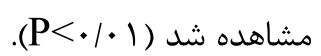

بر همين اساس، اين كاهش در مؤلفه يرخاشكرى فيزيكى

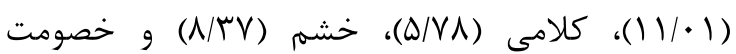

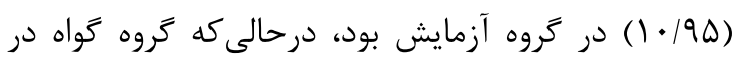

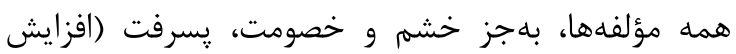
يرخاشكرى) در ميانكين داشت و در خشم و خصومت نيز

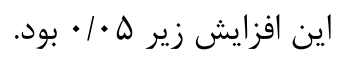

ثابت نتخهداشتن اثر متغيرهاى مخدوشكنيند (سن، تحصيلات، شغل، محل سكونت) در دو كروه بررسى شد.

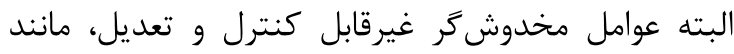

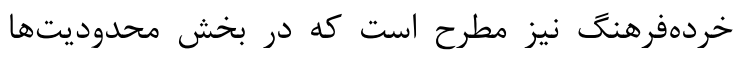
ذكر شد و قابل تعديل نبودند. اما در نهايت، تصميم درديم

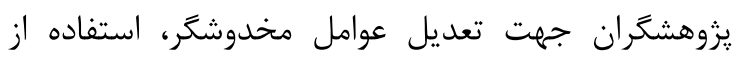

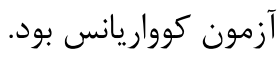

\section{يافته ها}

يزوهش حاضر در يى بررسى اين فرضيه صورت يذيرفت

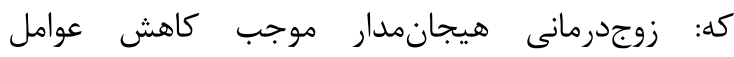
يرخاشكرى ارتباطى زوجهاى داراى زنان مبتلا به سرطان

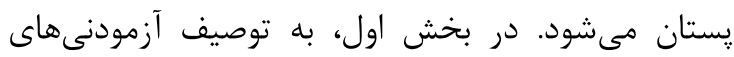
تحقيق يرداخته شد. شركت كنندكان در اين مطالعه تعداد

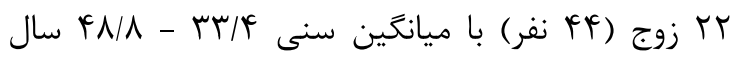

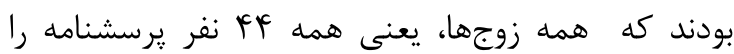

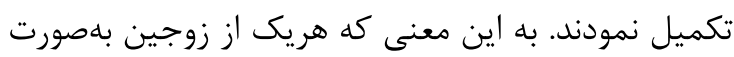

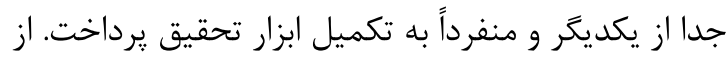

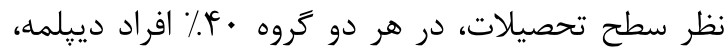

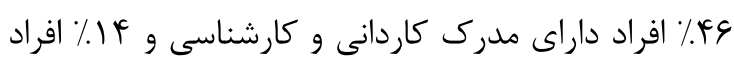
داراى مدرى كارشناسى ارشد و بالاتر بودند.

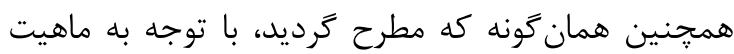

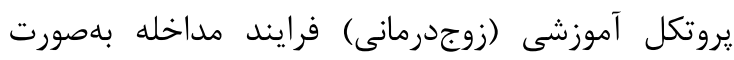

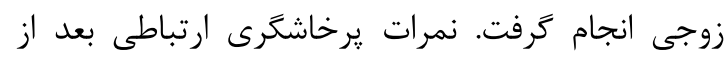

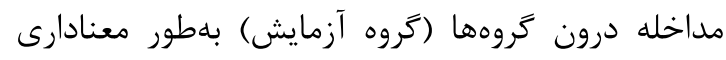

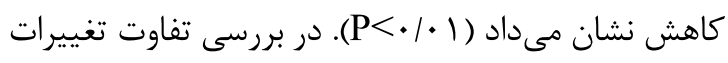

جدول r: مشخصات دموكَ افيك شركت كنندگًان در هزوهش

\begin{tabular}{|c|c|c|c|c|}
\hline كروه كواه & كرووه آزمايش & متغير & جنسيت & مشخصات \\
\hline$F V / T V \pm q / \cdot 1$ & $F r / V Y \pm \Delta / V I$ & (ميانغين / انحراف معيار) & 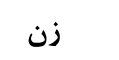 & \multirow{2}{*}{ سن (سال) } \\
\hline$\Delta r / \Delta F \pm I I / V \Lambda$ & $Y \wedge / T V \pm V / T \Lambda$ & (ميانگين/ انحراف معيار) & 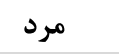 & \\
\hline$(/ \uparrow \Delta) \Delta$ & $(/ . r \varepsilon)^{f}$ & دييلم (فراوانى/ درصد) & \multirow{4}{*}{ 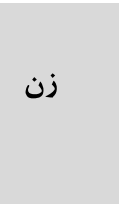 } & \multirow{6}{*}{ تحصيلات } \\
\hline$(/ . \Delta Q) \&$ & $(1.94) \mathrm{V}$ & كاردانى و كارشناسى (فراوانى/ درصد) & & \\
\hline-- & -- & كارشناسى ارشد و بالاتر (فراوانى/ درصد) & & \\
\hline$(/ . r \varepsilon / T \Delta) F$ & $(/ \mp \Delta) \Delta$ & دييلم (فراوانى / درصد) & & \\
\hline$(/ . r \varepsilon / T \Delta) F$ & $(/ . r V / Q) r$ & كاردانى و كارشناسى (فراوانى / درصد) & \multirow[t]{2}{*}{ 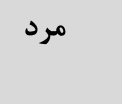 } & \\
\hline$(/ . r V / Q) r$ & $(/, T V / D) r$ & كارشناسى ارشد و بالاتر (فراوانى/ درصد) & & \\
\hline$(\% 19) r$ & $(/, r \Lambda) r$ & شاغل (فراوانى/ درصد) & \multirow{3}{*}{ 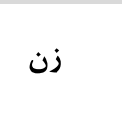 } & \multirow{4}{*}{ 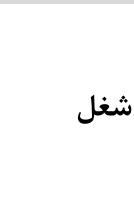 } \\
\hline$(/ .11) 9$ & $(/ V Y) \wedge$ & بيكار (فراوانى/ درصد) & & \\
\hline$(1.94) \vee$ & $(/ .11)^{9}$ & شاغل (فراوانى/ درصد) & & \\
\hline$(/ . r \varepsilon)^{q}$ & $(\% 19) r$ & بيكار (فراوانى/ درصد) & 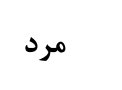 & \\
\hline
\end{tabular}




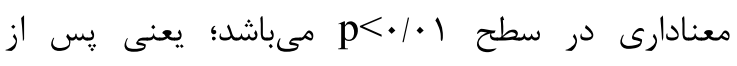

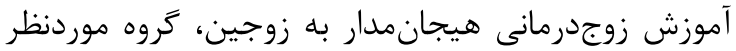
(آزمايش) بهطور معنادارى بيش از كروه كواه به سوالات

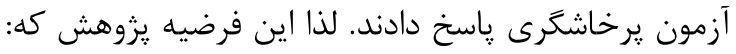

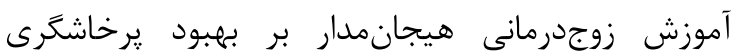
ارتباطى زوجهاى داراى زنان مبتلا به سرطان يستان، مؤثر

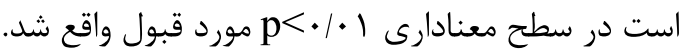

در ادامه، به تحليل كوواريانس جهت بررسى اثربخشى مداخله مورد نظر و مقايسه با كروه كنترل يرداخته شد.

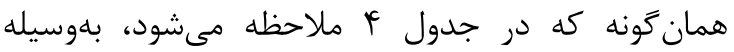
تحليل كوواريانس، معنادارى تفاوت بين ميانكينهاى

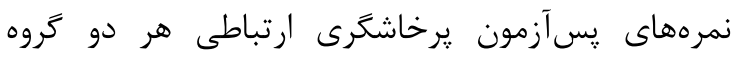

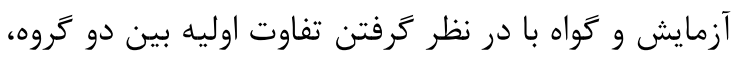

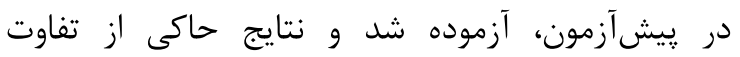

جدول بّ: ميانكين و انحراف معيار نمرات مؤلفههاى ثرخاشَّى در دو كروه، قبل و بعد از مداخله به تفكيك جنسيت

\begin{tabular}{|c|c|c|c|c|c|}
\hline \multicolumn{2}{|c|}{ كواه (SD \pm Mean) } & \multicolumn{2}{|c|}{ آزمايش (SD $($ Mean) } & \multirow{2}{*}{ زمان } & \multirow{2}{*}{ متغير } \\
\hline مرد & 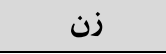 & مرد & زن & & \\
\hline$r F / \cdot 1 \pm r / r \Delta$ & $r F / r q \pm \psi / \cdot 1$ & $r r / r V \pm r / 19$ & $r T / r \mid \pm r / 11$ & ي ״يش آزمون & \\
\hline$r F / 11 \pm r / q r$ & $r F / r \mid \pm r / q 1$ & $r T / T I \pm Y / I F$ & $r \cdot / \uparrow \Delta \pm r / 1$. & يسآزمون & فيزيكى \\
\hline .1941 &.$/ 99$. & $<\cdot / \cdot \bullet 1$ & $<\cdot / \cdot \bullet$ & P-Value & \\
\hline $\mid V / Q r \pm r / 9 \varphi$ & $|N /| r \pm r / q r$ & $19 / 4 r \pm r / \cdot 1$ & $1 \Lambda / r \Delta \pm r / V r$ & ي پِيشآزمون & \\
\hline $\mid \vee / 9 \Delta \pm \Gamma / \Lambda \Lambda$ & $1 N / 1 r \pm r / 9$. & $|r / T \cdot \pm r /| \mid$ & $\mid r / \cdot r \pm r / r V$ & يس پآزمون & كلامى \\
\hline.$/ 918$ & . /994 & $<\bullet / . \bullet 1$ & .1 .94 & P-Value & \\
\hline$r r / 11 \pm r / / r$ & $r r / q q \pm r / l 1$ & $r r / 9 V \pm r / 9 \varphi$ & $r r / / q \pm r / l$. & ي ״يش آزمون & \\
\hline$r \mid / 9 \Delta \pm r / .9$ & $r r / \cdot r \pm r / 19$ & $\mid \Delta / q r \pm r / \cdot 1$ & $|g / F \cdot \pm r / r|$ & يسآزمون & خشم \\
\hline$\cdot 19 \cdot 0$ & . $194 \wedge$ & $<\cdot / \cdot \cdot 1$ & $.1 \cdot 1$ & P-Value & \\
\hline$r q / \mid r \pm r / r)$ & $r q / \Delta \Lambda \pm r / F r$ & YN/TrET/q. & $r \cdot / \cdot r \pm r / \cdot r$ & ي پِيش آزمون & \\
\hline$r q / r q \pm r / r \Delta$ & $r q / 1 \cdot \pm r / 11$ & $I V / 9 \Delta \pm r / \mid r$ & $|N / \Delta| \pm r / \Delta \mid$ & 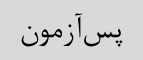 & خصومت \\
\hline .1949 & - /vqF & $<\cdot / \cdot \cdot 1$ & $<\cdot 1 \cdot \cdot 1$ & P-Value & \\
\hline
\end{tabular}

جدول f: نتايج حاصل از تحليل كوواريانس بر روى ميانكين نمرههاى برخاشكرى بس آزمون آزمودنىهاى كروه آزمايش و كَواه

\begin{tabular}{|c|c|c|c|c|c|c|}
\hline Sig & $\mathbf{F}$ & MS & df & SS & منبع هراش & مؤلفه \\
\hline \multirow[t]{2}{*}{$\cdot 1 \cdot 1$} & $\vee / \wedge \wedge 9$ & TYN/TAI & 1 & TFN/YAI & شرايط آزمايشى & فيزيكى \\
\hline & & TI/TG & 19 & $\Delta q F / \| \Delta$ & خطا & \\
\hline \multirow[t]{2}{*}{$\cdot 1 \cdot \cdot 1$} & $\Delta / \Lambda \Lambda F$ & 19N/TrT & 1 & 19N/TrT & شرايط آزمايشى & كلامى \\
\hline & & $r I / r r$ & 19 & $F / r / \Lambda \Lambda$ & خطا & \\
\hline \multirow[t]{2}{*}{$\cdot 1 \cdot 1$} & V/FYA & $511 / 110$ & 1 & $511 / 110$ & شرايط آزمايشى & خشم \\
\hline & & $r r / r F$ & 19 & FFr/DQT & خطا & \\
\hline \multirow[t]{2}{*}{$\cdot 1 \cdot 1$} & $1 \cdot \operatorname{LSGT}$ & TrT/IDO & 1 & rtr/IDO & شرايط آزمايشى & خصومت \\
\hline & & rG/VF & 19 & $\Delta \cdot N / r r q$ & خطا & \\
\hline
\end{tabular}

كنترل صورت پذيرفت. پِ از كنترل اثر پيشآزمون، فرضيه يزوهش، يعنى اثربخشى زوجدرمانى هيجانمدار بر

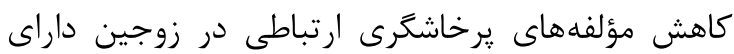

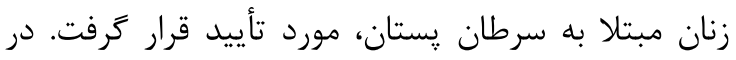

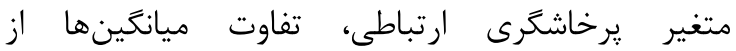

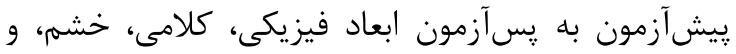

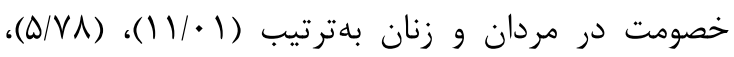

هدف از يزوهش حاضر، بررسى اثربخشى زوجدرمانى

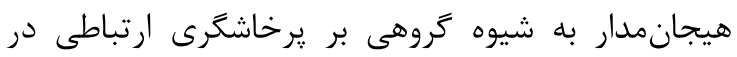

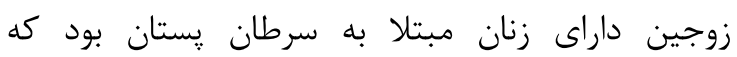
بهصورت يك يزوهش از نوع كارآزمايى بالينى كنترلشده

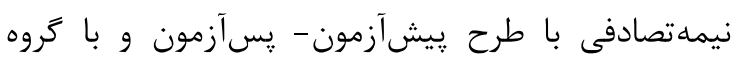


تداوم و حفظ اين مؤلفهها مىشود (ع) كه نشان از تأييد

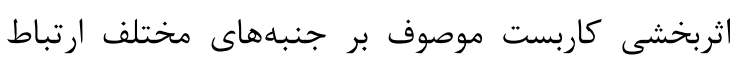

زوجى داشته و تصديقگر نتايج مطالعه حاضر مىباشد.

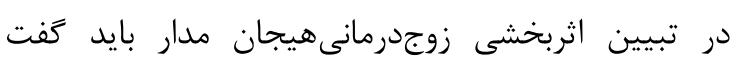

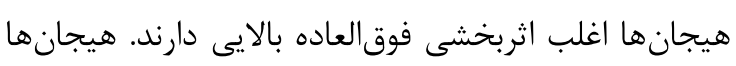

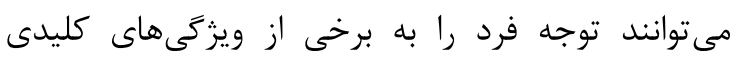

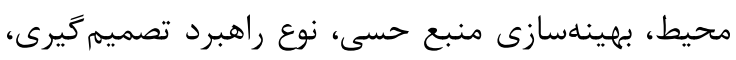

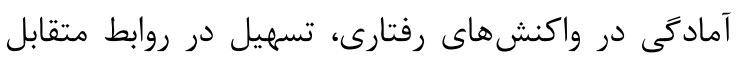

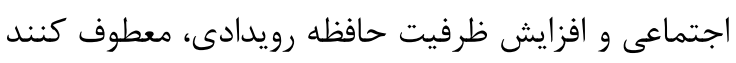
(DF)

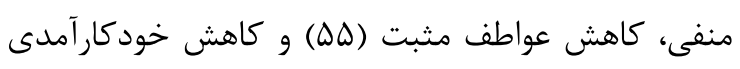

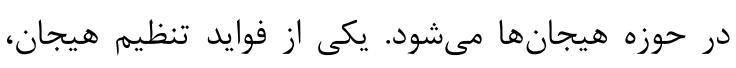

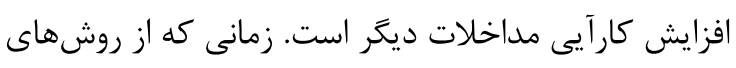

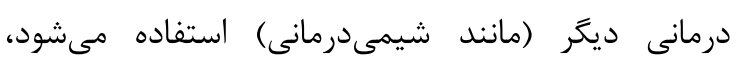

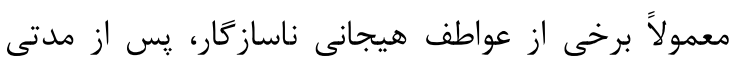

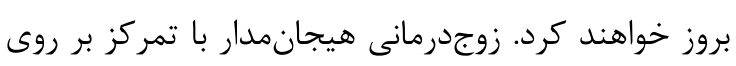

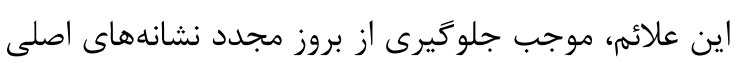

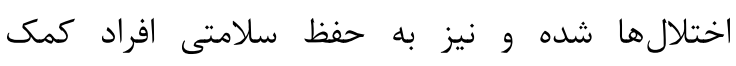

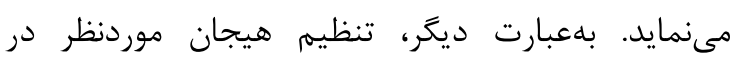

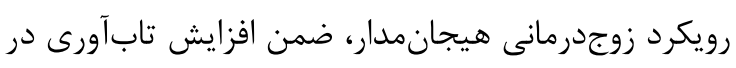

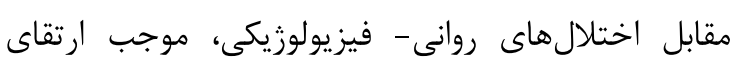

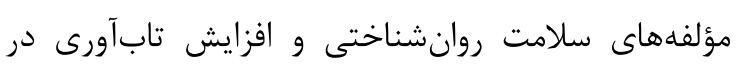

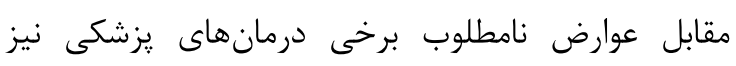

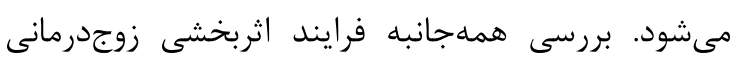

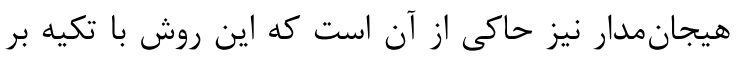

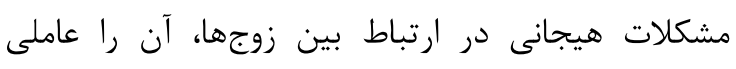

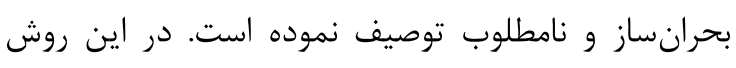

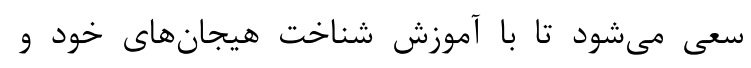

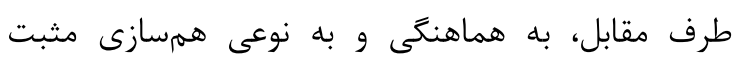

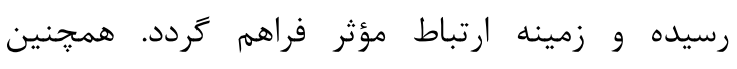

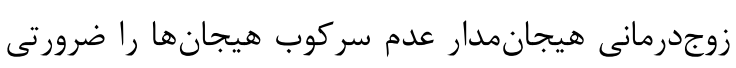

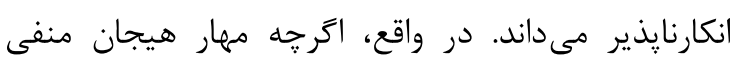

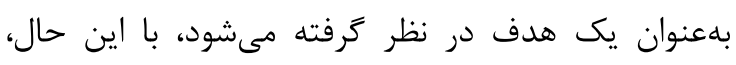

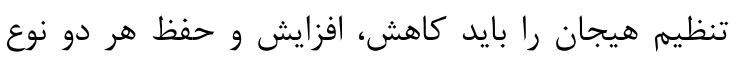

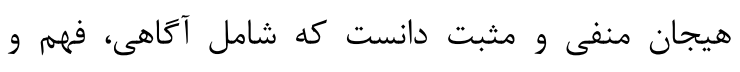

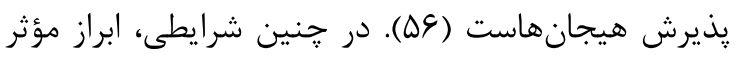

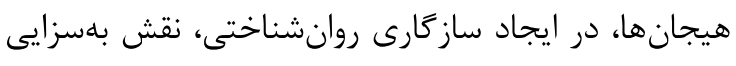

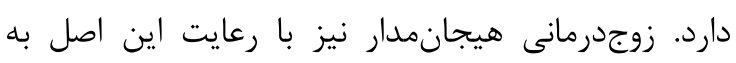
زوجين در اظهار و بيان مطلوب هر دو نوع هيجان مثبت و وداني
(N/TV)

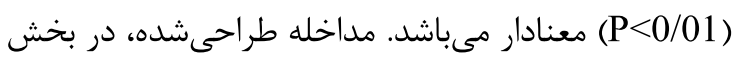

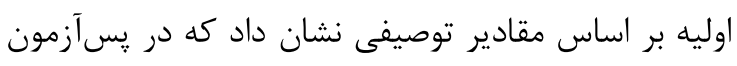

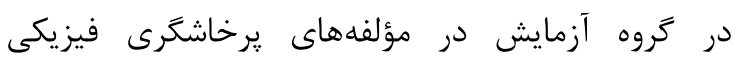

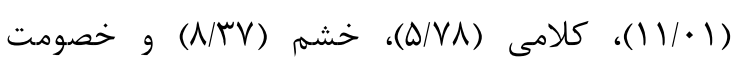

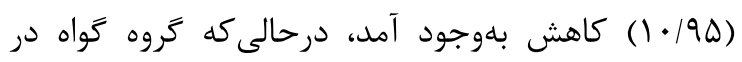

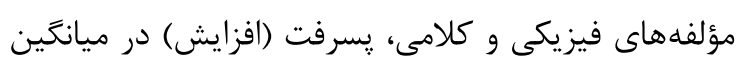

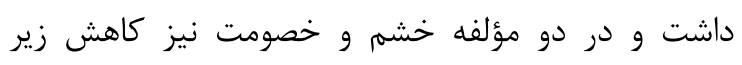

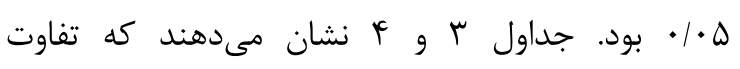

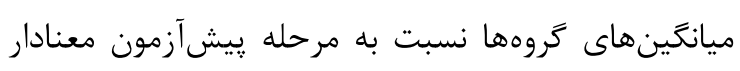

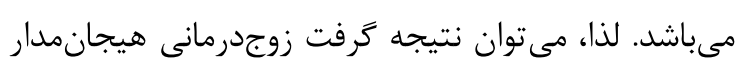

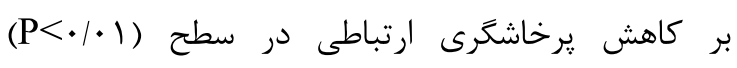

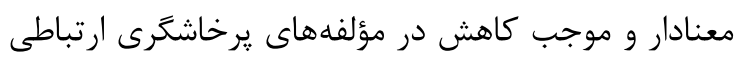
(فيزيكى، كلامى، خشم، و خصومت) در زوجهاى دار داراى مؤلى زنان مبتلا به سرطان يستان شده است. نتايج يزوهش حاضر، همراستا با مطالعه شاهمرادى و و ماندان

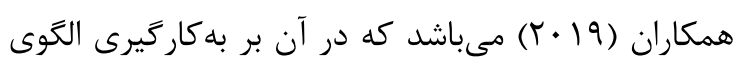

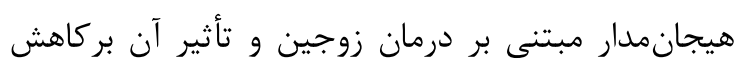

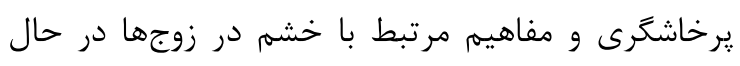

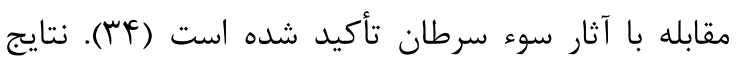

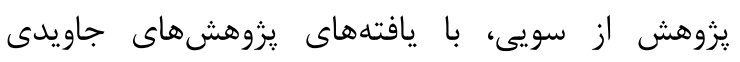

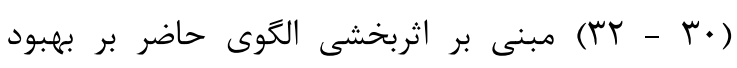

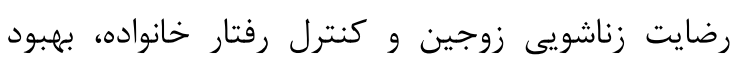

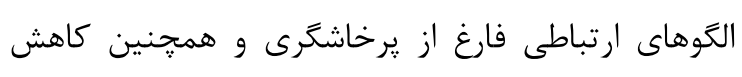

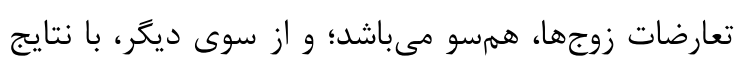

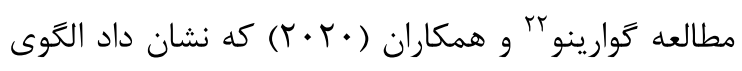

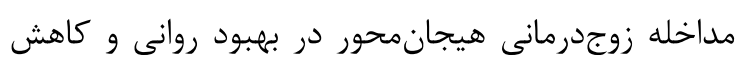
استرس و تظاهرات يرخاشكرايانه در زنان مبتلا به سرطان دران

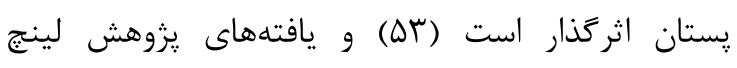

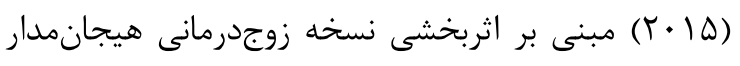

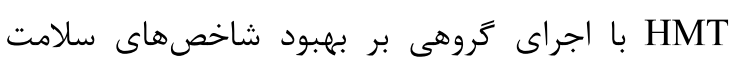

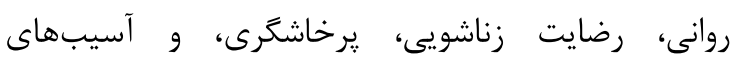

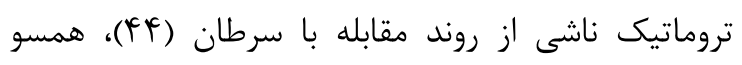

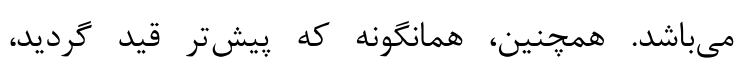

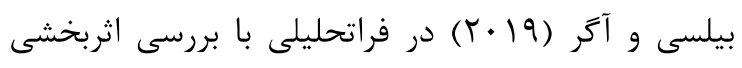

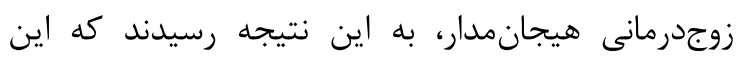

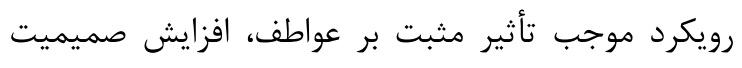

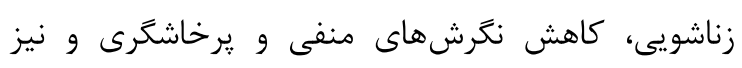

${ }^{22}$ Guarino 
مىشود. در بررسى عميقتر اثربخشى اين رويكرد در

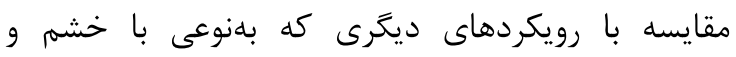

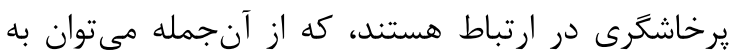

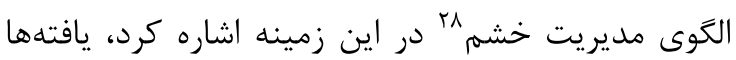
بيانكر اين موضوع بود كه برنامههايى همجِون مديريت إندائ خشم نيز در كاهش يرخاشكرى ارتباطى تاثير دارند، اما

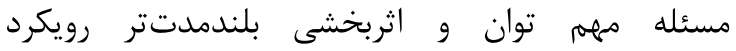

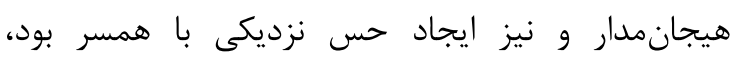
درحالى كه توجه برنامه هايى همجرون مديريت خشم عمدتاً

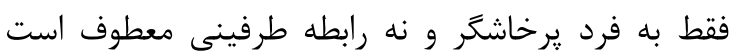

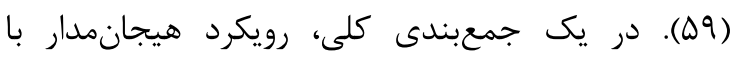

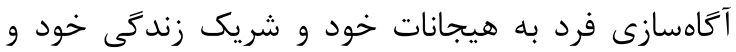
تقويت احساس احترام به خويشتن و ديكرى در محيطى

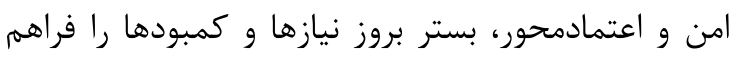
آورده و با ايجاد يك محيط ارتباطى مناسب، زمينه حل يل ئل مشكلات، نزديكى هيجانى، احساس صميميت زوجين و

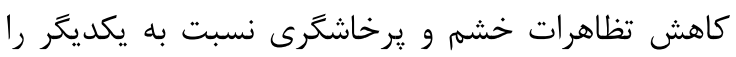

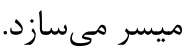
از نقاط ضعف مطالعه، تك مركزى بودن و اجراى مطالعه در يك نوع خاص از سرطان (سرطان يستان) را ميتوان

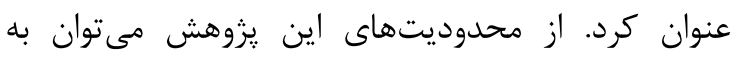

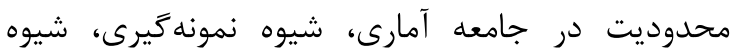

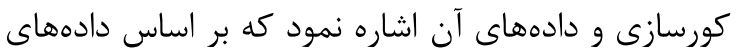

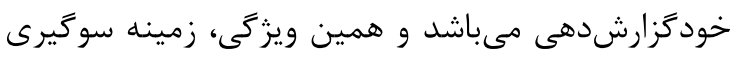

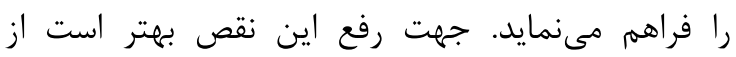

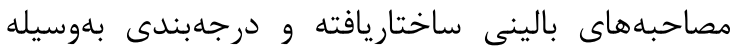

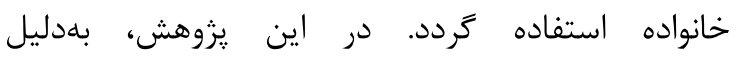
محدوديتها، از روش نمونه گيرى دردسترس استفاده شد؛

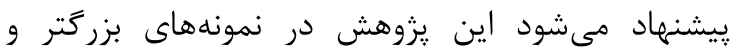

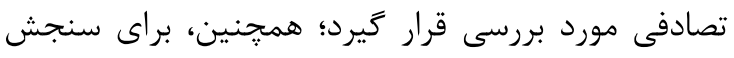

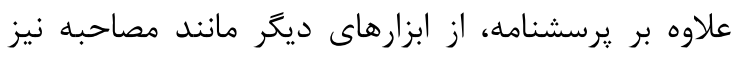

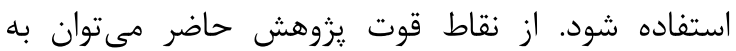
بررسى اثربخشى زوجدرمانى هيجانمدار بر يرخاشكرى

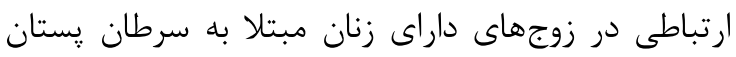

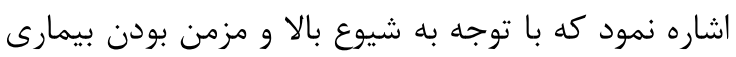

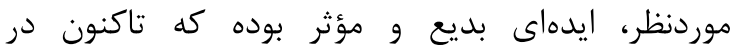
يزوهشهاى داخلى بهكار كرفته نشده و مى بوتواند در آينده

${ }^{28}$ Anger Management Model
منفى و بروز مناسب آن كمك نموده و زمينه را براى

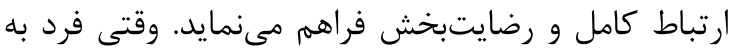
سطح مطلوب عاطفى و هيجانى برسد و بتواند در خانواده

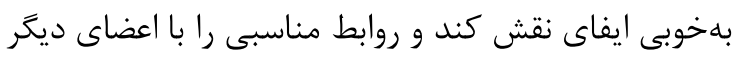

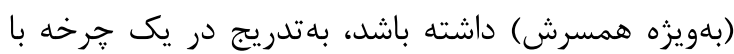

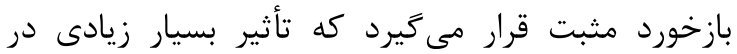

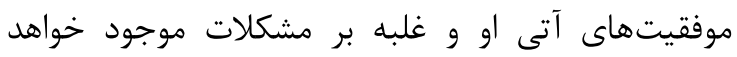

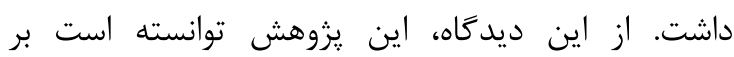

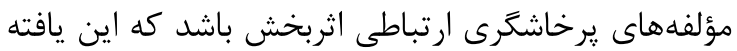

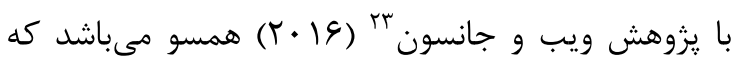

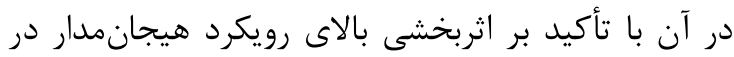

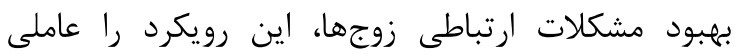
اثركذار و تغييردهنده در مشكلات ارتباط زناشويى در ابعاد

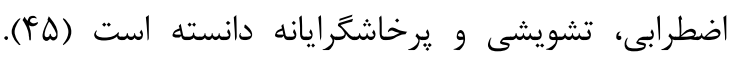

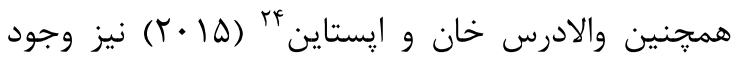
محركهاى منفى هيجانى و بى توجهى به همسر و طرف

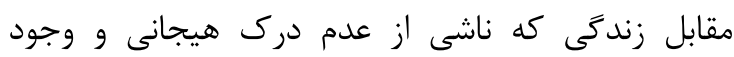



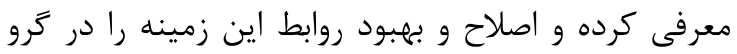

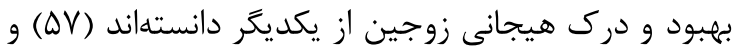
لذا نتايج يزوهش حاضر با مطالعه يادشده نيز همراستا

زوجدرمانى هيجانمدار با بهرهيرى از رويكردى يكيارجه

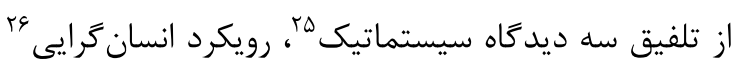

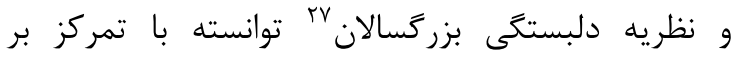

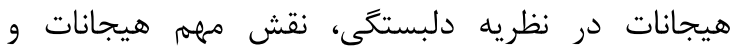

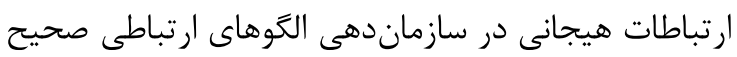

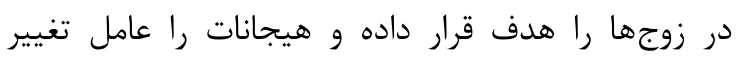

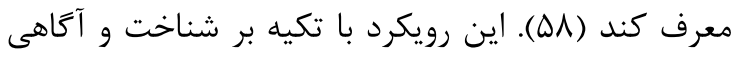
زوجين نسبت به هيجانات يكديكر، نزديكى و تشريك در

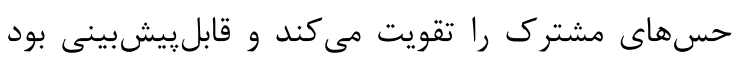

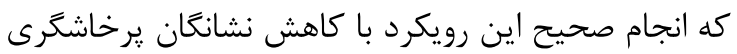
در ابعاد مختلف در مؤلفههاى فيزيكى، كلامى، خشم، و و

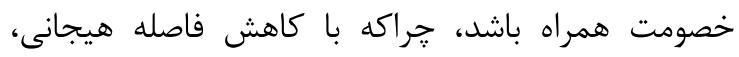
زمينه نزديكى احساسات و عواطف و ارتباط متقابل تقويت همراه بأن

\footnotetext{
${ }^{23}$ Wiebe \& Johnson

${ }^{24}$ Valladares Khan \& Epstein

${ }^{25}$ Systematic Approach

${ }^{26}$ Humanistic Approach

${ }^{27}$ Adult Attachment Theory
} 
هيجانها در الكوهاى ارتباطى ميان زوجها است؛ بهويثه زمانى كه يكى از زوجين به بيمارىهاى مزمن يزشكى مبتلا مى گردد و از اين طريق مى توان به ايشان در كنار

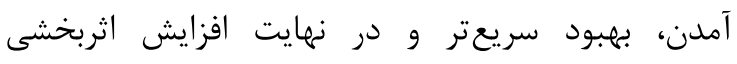
درمانهاى يزشكى كمك شايانى نمود. شايان ذكر است استفاده از مداخلات رواندرمانى از ابتداى درمان تان زمان فراغت از بيمارى، نهتنها موجب حفظ تعادل و سلامت روانى در بيماران و خانواده آنها (بهويزه همسرانشان) مىشود، بلكه ميزان يايبندى افراد به توصيه هاى يرشكى را ميز افزايش مى مهد.

\section{تشكر و قدرداني}

يروهشَران وظيفه خود مىدانند از تمامى كسانى كه

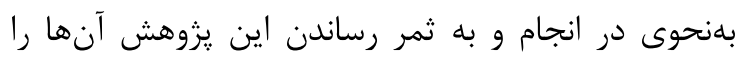
يارى نمودند، و همجنين كليه مسئولين و كادر درمان مركز توانبخشى آرمان شايان (تهران) (بهعنوان محل اجراى طرح) و مسئولين دانشگاه علوم يزشكى هرمز گان

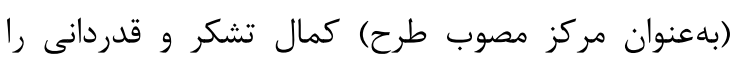
داشته باشند.

\section{تعارض منافع}

نويسندگان اين مقاله اظهار مىدارند كه هيجزَّنه تعارض منافعى در انجام و انتشار نتايج اين يروهش ندارند.

$$
\begin{aligned}
& \text { درخصوص جنبههاى مختلف زندگى اين قبيل زوجها }
\end{aligned}
$$

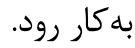

$$
\begin{aligned}
& \text { ييشنهاد مىشود اين كاربست بر روى جامعه آمارى ساير } \\
& \text { زوجها كه داراى انواع ديخرى از بيمارىهاى مزمن يزشكى } \\
& \text { مىباشند، نيز صورت گذيرد. بهعلاوه، اجراى اين برنامه } \\
& \text { آموزشى در ساير جوامع بالينى و غيربالينى، موجب تبيين } \\
& \text { بهتر فرايند اثربخشى آن خواهد شد. بنابر نتايج اين بن }
\end{aligned}
$$

بهوروكلى، نتايج يزوهش حاضر، نشان از تأثير معنادار

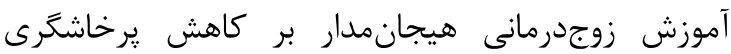
ارتباطى زوجها و بهبود در مؤلفههاى آن و در نتيجه بهبود فرايندهاى هيجانى در رابطه بين زوجها داشت. الگوى اين معنادارى نشان داد با بهكارگيرى صحيح و كارآمد اين رين بندين رويكرد مىتوان در درى هيجانى و نزديكى زوجين نسبت

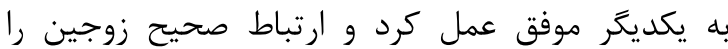
تقويت نمود. همجنين، نتايج حاكى از نقش يررنت و مؤثر

4. Safaee A, Zeighami B, Tabatabaee HR, Moghimi Dehkordi B. Quality of life and Related Factors in Breast Cancer Patients under Chemotherapy. Iranian Journal of Epidemiology. 2008; 3(4):61-6.

5. McPherson K, Steel CM, Dixon JM. ABC of breast diseases. Breast cancer-epidemiology, risk factors, and genetics. BJM. 2000; 321(7261): 624-8.

6. Mohammadi E, Aminorroaya A, Fattahi N, Azadnajafabad S, Rezaei N, Farzi Y, Naderimagham S, Rezaei N, Larijani B, Farzadfar F. Epidemiologic pattern of cancers in Iran; current knowledge and future perspective. Journal of Diabetes \& Metabolic Disorders. 2020; 20:1-5. 
7. Danaei G, Farzadfar F, Kelishadi R, Rashidian A, Rouhani OM, Ahmadnia S, Ahmadvand A, Arabi M. Review Iran in transition. Lancet. 2019; 393:1984-2005.

8. Iranian Ministry of Health and Education. [Annual Report of Iranian National Population-Based Cancer Registry]. 2015.

9. Ataollahi MR, Sharifi J, Paknahad MR, Paknahad A. Breast cancer and associated factors: a review. J Med Life. 2015; 8:6-11.

10. Fazel A, Hasanpour-Heidari S, Salamat F, Rajaie S, Kazeminezhad V, Naeimi-Tabiei M, Jahangirrad A, Sedaghat S, Hosseinpoor R, Ghasemi-Kebria F, Roshandel G. Marked increase in breast cancer incidence in young women: A 10-year study from Northern Iran, 2004-2013. Cancer epidemiology. 2019; 62(1): 101573.

11. Heer E, Harper A, Escandor N, Sung H, McCormack V, Fidler-Benaoudia MM. Global burden and trends in premenopausal and postmenopausal breast cancer: a populationbased study. The Lancet Global Health. 2020; 8(8):e1027-37.

12. WHO. Global Cancer Country Profile 2020. [Internet]. 2020 [cited 2020 Nov 9]. Available from: https://www.who.int/docs/defaultsource/ documents/health-topics/ cancer/global-country-profiles-on-burdenof-cancer-a-to-k.pdf?sfvrsn=45c42531_4.

13. Ziner KW, Sledge GW, Bell CJ, Johns S, Miller KD, Champion VL. Predicting fear of breast cancer recurrence and self-efficacy in survivors by age at diagnosis. Oncol Nurs Forum. 2012; 39(3):287-95.

14. Ferrell B, Grant M, Funk B, Otis-Green S, Garcia N. Quality of life in breast cancer: Part II: Psychological and spiritual wellbeing. Cancer Nursing. 1998; 21(1):1-9.

15. Vickberg SM. Fears about breast cancer recurrence. Cancer Practice. 2001; 9(5): 237-243.

16. Yang HC, Schuler TA. Marital quality and survivorship: slowed recovery for breast cancer patients in distressed relationships. Cancer. 2009; 115(1):217-28.

17. Lovner J. Karney B. Bradbury T. Does Couples' Communication Predict Marital Satisfaction, or Does Marital Satisfaction Predict Communication? Journal of Marriage and Family, 2016; 78(3): 680-94.

18. Malary M. Shahhosseini Z. Pourasghar M. Hamzehgardeshi Z. Couples Communication Skills and Anxiety of Pregnancy: A Narrative Review. Materia Socio-Medica, 2016; 27(4): 286-90.
19. Villa MB. Zilda A.P. Marital Satisfaction: The Role of Social Skills of Husbands and Wives. Paidéia (Ribeirão Preto), 2013; 23(56): 37988.

20. Fakhraee S. Bashiri Khatibi B. Social and Cultural Factors Influencing Family Violence in Tabriz. Journal of Applied Sociology. 2013; 24(2):221-33.

21. Hammett JF, Lavner JA, Karney BR, Bradbury TN. Intimate Partner Aggression and Marital Satisfaction: A Cross-Lagged Panel Analysis. J Interpers Violence. 2017; 4:88-99.

22. Testa M. Leonard KE. The Impact of Marital Aggression on Women's Psychological and Marital Functioning in a Newlywed Sample. Journal of Family Violence 2001; 16:115-30.

23.Zimmermann T. Intimate Relationships Affected by Breast Cancer: Interventions for Couples. Breast Care (Basel). 2015; 10(2): 102-8.

24. Coker AL, Follingstad DR, Garcia LS, Bush $\mathrm{HM}$. Intimate partner violence and women's cancer quality of life. Cancer Causes Control. 2017; 28(1):23-39.

25. Keltner D, Sauter D, Tracy J, Cowen A. Emotional Expression: Advances in Basic Emotion Theory. J Nonverbal Behav. 2019; 43(2):133-60.

26. Beasley CC, Ager R. Emotionally Focused Couples Therapy: A Systematic Review of Its Effectiveness over the past 19 Years. J Evid Based Soc Work. 2019; 16(2):144-59.

27. Denton WH, Johnson SM, Burleson BR. Emotion-focused therapy-therapist fidelity scale (EFT-TFS): Conceptual development and content validity. Journal of couple \& relationship therapy. $2009 ; 8(3)$ : 226-46.

28. Johnson SM. The revolution in couple therapy: A practitioner-scientist perspective. Journal of marital and family therapy. 2003; 29(3): 365-84.

29. Denton WH, Wittenborn AK, Golden RN. Augmenting antidepressant medication treatment of depressed women with emotionally focused therapy for couples: A randomized pilot study. Journal of Marital and Family Therapy. 2012; 38:23-38.

30. Javidi N. The effectiveness of emotionally focused couples therapy (EFCT) in improving marital satisfaction and family behavior control. Biannua Journal of Applied Counseling. 2013; 3(2):65-78.

31. Javidi N, Soleimani A, Ahmadi Kh SM. The effectiveness of training of emotion management strategies according to emotionally focused couple therapy (EFT) to 
increase sexual satisfaction in couples. $\mathbf{J}$ Health Psychol. 2012; 1(3):5-18.

32. Javidi N, Soleimani A, Ahmadi Kh, Samadzadeh M. The effectiveness of emotionally focused couples therapy (EFT) to improve communication patterns in couples. $\mathrm{J}$ Res Behave Sci. 2014; 11(5):402-10.

33. Karimi J, Sodani M, Mehrabizade M, Neisi A. Comparison of the efficacy of integrative couple therapy and emotionally focused couple therapy on symptoms of depression and posttraumatic stress symptoms caused by extra-marital relations in couples. $\mathrm{J}$ Clin Psychol. 2013; 3(19):35-47.

34. Shahmoradi S, Keshavarz Afshar H, Goudarzy M, Gholam Ali Lavasani M. Effectiveness of Emotion-Focused Therapy in Reduction of Marital Violence and Improvement of Family Functioning: A Quasi-Experimental Study. Iranian Red Crescent Medical Journal. 2019; 21(11): e97183.

35. Babaei Gharmkhani M, Rasouli M, Davarniya R. The Effect of Emotionally-Focused Couples Therapy (EFCT) on Reducing Marital Stress of Married Couples. Zanko J Med Sci. 2017; 18(56):56-69.

36. Raisi J, Mohammadi K, Zarei I, Najar Pourian S. Comparison of the effectiveness of emotion-based couple therapy and re-decision approach on increasing the resilience of married women. Islamic Journal of Women and Family, 2019; 6(3): 33-48.

37. Davarnia R, Zahrakar K, Moayeri N, Shakerami M. The effectiveness of emotionoriented couple therapy in a group method on reducing female marital burnout. Quarterly Journal of Medical Sciences, Islamic Azad University, Tehran Medical Branch, 2015; 25(2): 132-140.

38. Walker JG, Manion IG, Cloutier PF, Johnson SM. Measuring marital distress in couples with chronically ill children: The Dyadic Adjustment Scale. Journal of Pediatric Psychology. 1992; 17(3):45-57.

39. Cloutier PF, Manion IG, Walker JG, Johnson SM. Emotionally focused interventions for couples with chronically ill children: A 2-year follow-up. Journal of marital and family therapy. 2002; 28(4):391-8.

40. Mclean L. M, Walton T, Rodin G, Esplen M. J, \& Jones J. M. A couple-based intervention for patients and caregivers facing end-stage cancer: Outcomes of a randomized controlled trial. Psycho-Oncology. 2013; 22: 28-38.

41. Grayer J. Emotionally focused therapy for couples: a safe haven from which to explore sex during and after cancer. Sexual and Relationship Therapy. 2016; 31(4):488-92.
42. Adamson NA. Emotionally focused therapy with couples facing breast cancer: a theoretical foundation and descriptive case study. Journal of psychosocial oncology. 2013; 31(6):712-26.

43. McLean LM, Hales S. Childhood trauma, attachment style, and a couple's experience of terminal cancer: Case study. Palliative \& supportive care. 2010; 8(2):227-33.

44. Lynch LE. Couples coping with cancer: A Hold Me Tight pilot intervention study [Doctoral dissertation]. Philadelphia: Drexel University; 2015.

45. Wiebe SA, Johnson SM. A review of the research in emotionally focused therapy for couples. Family Process. 2016; 55(3):390-407.

46. Naaman SC. Evaluation of the clinical efficacy of emotionally focused couples therapy on psychological adjustment and natural killer cell cytotoxicity in early breast cancer [Doctoral dissertation]. University of Ottawa; 2008.

47. McLean LM, Jones JM, Rydall AC, Walsh A, Esplen MJ, Zimmermann C, Rodin GM. A couples intervention for patients facing advanced cancer and their spouse caregivers: Outcomes of a pilot study. Psycho-Oncology: Journal of the Psychological, Social and Behavioral Dimensions of Cancer. 2008; 17(11): 1152-6.

48. Akram M, Iqbal M, Daniyal M, Khan AU. Awareness and current knowledge of breast cancer. Biological research. 2017; 50(1):33.

49. Buss AH, Perry $M$. The aggression questionnaire. J Pers Soc Psychol. 1992; 63(3):452-9.

50. Sanaei Zaker B, Barati T. Family and marriage scales. Tehran: Besat publication; 2000.

51. Samani S. Study of reliability and validity of the Buss and Perry's aggression questionnaire. Iranian journal of psychiatry and clinical psychology. 2008; 13(4):359-65.

52. Davey M, Liu TK. Couples Coping with Cancer: Hold Me Tight Pilot Intervention Study. Internal Seed Grant, DUCOM Radiation Oncology Department. Philadelphia: Drexel University; 2013.

53. Guarino A, Polini C, Forte G, Favieri F, Boncompagni I, Casagrande M. The Effectiveness of Psychological Treatments in Women with Breast Cancer: A Systematic Review and Meta-Analysis. J Clin Med. 2020; 9(1): 209.

54. Gross JJ. Handbook of emotion regulation. New York: Guilford Press; 2014.

55. Berking M, Orth U, Wupperman P, Meier LL \& Caspar F. Prospective effects of emotion 
regulation skills on emotional adjustment. J Counsel Psychol. 2008; 55(4):485-94.

56. Gratz KL \& Tull MT. Emotion regulation as a mechanism of change in acceptance-and mindfulness-based treatments. In R. A. Baer (Ed.), Assessing mindfulness and acceptance: Illuminating the processes of change. Oakland, CA: New Harbinger Publications; 2010.

57. Valladares khan S. Epstein NB. Couple Therapy for Partner Aggression: Effects on Individual and Relational Well-Being. Journal of Couple \& Relationship Therapy 2015; 14(2):92-115.

58. Johnson SM. Creating connection: The practice of emotionally focused couple therapy. New York: Brunner-Routledge; 2004.

59. Crane CA, Testa M. Daily associations among anger experience and intimate partner aggression within aggressive and nonaggressive community couples. Emotion. 2014; 14(5):985. 